4

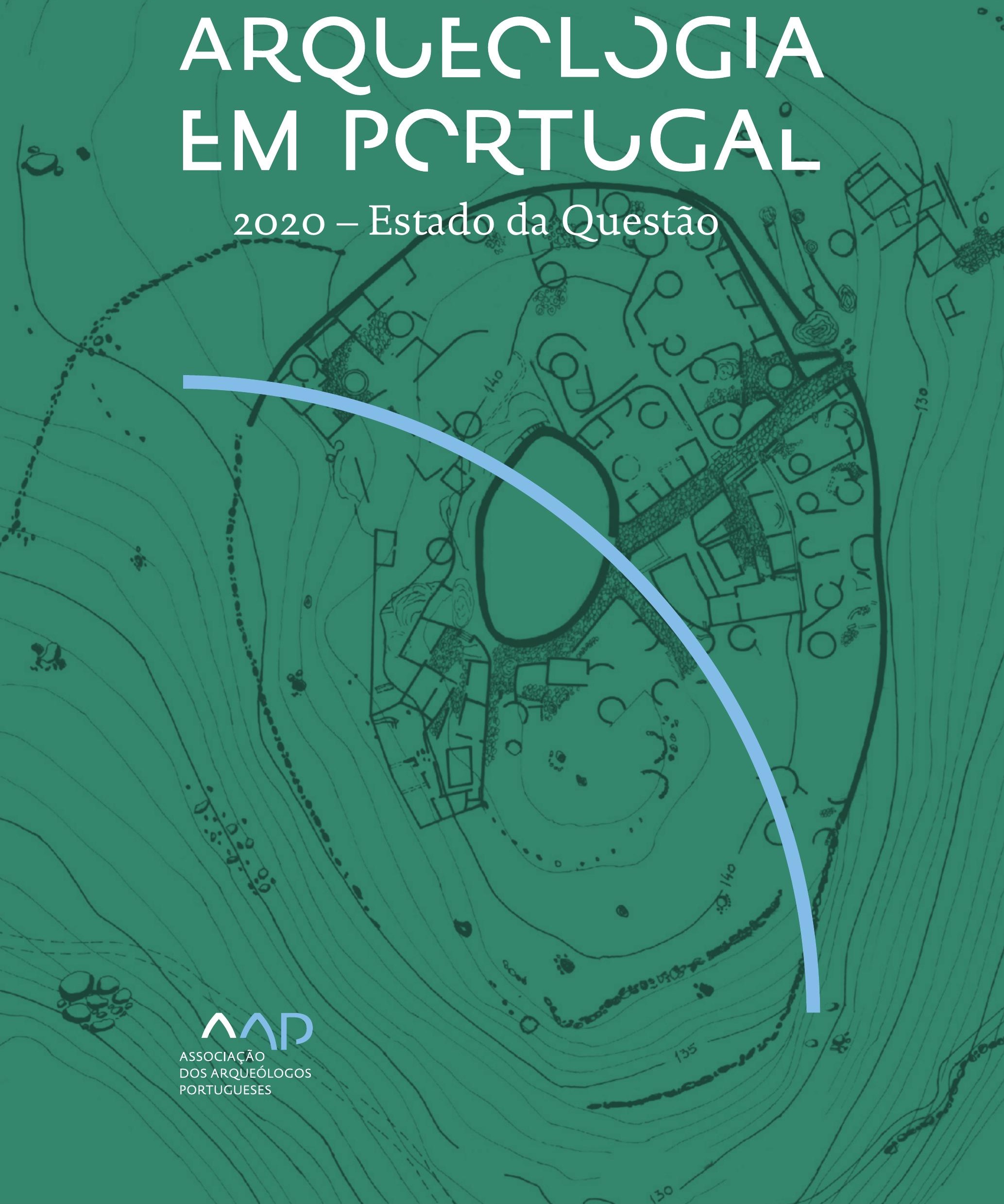


Coordenação editorial: José Morais Arnaud, César Neves e Andrea Martins Design gráfico: Flatland Design

AAP - ISBN: 978-972-9451-89-8

CITCEM - ISBN: 978-989-8970-25-1

Associação dos Arqueólogos Portugueses e CITCEM

Lisboa, 2020

O conteúdo dos artigos é da inteira responsabilidade dos autores. Sendo assim a Associação dos Arqueólogos Portugueses declina qualquer responsabilidade por eventuais equívocos ou questões de ordem ética e legal.

Desenho de capa:

Planta do castro de Monte Mozinho (Museu Municipal de Penafiel).

\section{$\hat{\wedge} \mathrm{P}$}

DOS ARQUEÓLOGOS PORTUGUESES

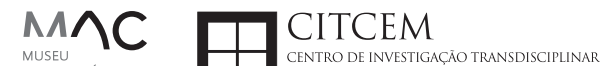
MUSEU
ARQUELLÓGICO
DO CARMO
U.PORTO

FLUP FACULDADE DE LETRAS
UNIVERSIDADE DO PORTO

Apoio

EC para a Ciência 


\section{Índice}

15 Prefácio

José Morais Arnaud

\section{Historiografia e Teoria}

17 Território, comunidade, memória e emoção: a contribuição da história da arqueologia (algumas primeiras e breves reflexões)

Ana Cristina Martins

25 Como descolonizar a arqueologia portuguesa?

Rui Gomes Coelho

41 Arqueologia e Modernidade: uma revisitação pessoal e breve de alguns aspetos da obra homónima de Julian Thomas de 2004

Vítor Oliveira Jorge

57 Dados para a História das Mulheres na Arqueologia portuguesa, dos finais do século XIX aos inícios do século XX: números, nomes e tabelas

Filipa Dimas / Mariana Diniz

73 Retractos da arqueologia portuguesa na imprensa: (in)visibilidades no feminino

Catarina Costeira / Elsa Luís

85 Arqueologia e Arqueólogos no Norte de Portugal Jacinta Bugalhão

101 Vieira Guimarães (1864-1939) e a arqueologia em Tomar: uma abordagem sobre o território e as gentes

João Amendoeira Peixoto / Ana Cristina Martins

115 Os memoráveis? A arqueologia algarvia na imprensa nacional e regional na presente centúria (2001-2019): características, visões do(s) passado(s) e a arqueologia

enquanto marca

Frederico Agosto / João Silva

129 A Evolução da Arqueologia Urbana e a Valorização Patrimonial no Barlavento Algarvio: Os casos de Portimão e Silves

Artur Mateus / Diogo Varandas / Rafael Boavida

\section{Gestão, Valorização e Salvaguarda do Património}

145 O Caderno Reivindicativo e as condições de trabalho em Arqueologia Miguel Rocha / Liliana Matias Carvalho / Regis Barbosa / Mauro Correia / Sara Simões / Jacinta Bugalhão / Sara Brito / Liliana Veríssimo Carvalho / Richard Peace / Pedro Peça / Cézer Santos

155 Os Estudos de Impacte Patrimonial como elemento para uma estratégia sustentável de minimização de impactes no âmbito de reconversões agrícolas Tiago do Pereiro

165 Salvaguarda de Património arqueológico em operações florestais: gestão e sensibilização Filipa Bragança / Gertrudes Zambujo / Sandra Lourenço / Belém Paiva / Carlos Banha / Frederico Tatá Regala / Helena Moura / Jacinta Bugalhão / João Marques / José Correia / Pedro Faria / Samuel Melro

179 Os valores do Património: uma investigação sobre os Sítios Pré-históricos de Arte Rupestre do Vale do Rio Côa e de Siega Verde José Paulo Francisco 
189 Conjugando recursos arqueológicos e naturais para potenciar as visitas ao Geoparque Litoral de Viana do Castelo (Noroeste de Portugal)

Hugo A. Sampaio / Ana M.S. Bettencourt / Susana Marinho / Ricardo Carvalhido

203 Áreas de Potencial Arqueológico na Região do Médio Tejo: Modelo Espacial Preditivo Rita Ferreira Anastácio / Ana Filipa Martins / Luiz Oosterbeek

223 Património Arqueológico e Gestão Territorial: O contributo da Arqueologia para a revisão do PDM de Avis

Ana Cristina Ribeiro

237 A coleção arqueológica do extinto Museu Municipal do Porto - Origens, Percursos e Estudos

Sónia Couto

251 Valpaços - uma nova carta arqueológica

Pedro Pereira / Maria de Fátima Casares Machado

263 Arqueologia na Cidade de Peniche

Adriano Constantino / Luís Rendeiro

273 Arqueologia Urbana: a cidade de Lagos como caso de Estudo Cátia Neto

285 Estratégias de promoção do património cultural subaquático nos Açores. O caso da ilha do Faial

José Luís Neto / José Bettencourt / Luís Borges / Pedro Parreira

297 Carta Arqueológica da Cidade Velha: Uma primeira abordagem

Jaylson Monteiro / Nireide Tavares / Sara da Veiga / Claudino Ramos / Edson Brito /

Carlos Carvalho / Francisco Moreira / Adalberto Tavares

311 Antropologia Virtual: novas metodologias para a análise morfológica e funcional Ricardo Miguel Godinho / Célia Gonçalves

\section{Didáctica da Arqueologia}

327 Como os projetos de Arqueologia podem contribuir para uma comunidade culturalmente mais consciente Alexandra Figueiredo / Claúdio Monteiro / Adolfo Silveira / Ricardo Lopes

337 Educação Patrimonial - Um cidadão esclarecido é um cidadão ativo! Ana Paula Almeida

351 A aproximação da Arqueologia à sala de aula: um caso de estudo no $3^{\circ}$ ciclo do Ensino Básico Luís Serrão Gil

363 Arqueologia 3.o - Pensar e comunicar a Arqueologia para um futuro sustentável Mónica Rolo

377 “Conversa de Arqueólogos" - Divulgar a Arqueologia em tempos de Pandemia Diogo Teixeira Dias

389 Escola Profissional de Arqueologia: desafios e oportunidades Susana Nunes / Dulcineia Pinto / Júlia Silva / Ana Mascarenhas

399 Os Museus de Arqueologia e os Jovens: a oferta educativa para o público adolescente Beatriz Correia Barata / Leonor Medeiros

411 O museu universitário como mediador entre a ciência e a sociedade: o exemplo da secção de arqueologia no Museu de História Natural e da Ciência da Universidade do Porto (MHNC-UP)

Rita Gaspar 
421 Museu de Lanifícios: Real Fábrica de Panos. Atividades no âmbito da Arqueologia Beatriz Correia Barata / Rita Salvado

427 Arqueologia Pública e o caso da localidade da Mata (Torres Novas) Cláudia Manso / Ana Rita Ferreira / Cristiana Ferreira / Vanessa Cardoso Antunes

431 Do sítio arqueológico ao museu: um percurso (também) didático Lídia Fernandes

447 Estão todos convidados para a Festa! E para dançar também... O projecto do Serviço Educativo do Museu Arqueológico do Carmo na $5^{\underline{a}}$ Edição da Festa da Arqueologia Rita Pires dos Santos

459 O “Clã de Carenque”, um projeto didático de arqueologia Eduardo Gonzalez Rocha

469 Mediação cultural: peixe que puxa carroça nas Ruínas Romanas de Troia Inês Vaz Pinto / Ana Patrícia Magalhães / Patrícia Brum / Filipa Santos

481 Didática Arqueológica, experiências do Projeto Mértola Vila Museu Maria de Fátima Palma / Clara Rodrigues / Susana Gómez / Lígia Rafael

\section{Arte Rupestre}

497 Os inventários de arte rupestre em Portugal Mila Simões de Abreu

513 O projeto FIRST-ART - conservação, documentação e gestão das primeiras manifestações de arte rupestre no Sudoeste da Península Ibérica: as grutas do Escoural e Maltravieso Sara Garcês / Hipólito Collado / José Julio García Arranz / Luiz Oosterbeek / António Carlos Silva / Pierluigi Rosina / Hugo Gomes / Anabela Borralheiro Pereira / George Nash / Esmeralda Gomes / Nelson Almeida / Carlos Carpetudo

523 Trabalhos de documentação de arte paleolítica realizados no âmbito do projeto PalæoCôa André Tomás Santos / António Fernando Barbosa / Luís Luís / Marcelo Silvestre / Thierry Aubry

537 Imagens fantasmagóricas, silhuetas elusivas: as figuras humanas na arte do Paleolítico Superior da região do Côa Mário Reis

$55^{1}$ Os motivos zoomórficos representados nas placas de tear de Vila Nova de São Pedro (Azambuja, Portugal) Andrea Martins / César Neves / José M. Arnaud / Mariana Diniz

571 Arte Rupestre do Monte de Góios (Lanhelas, Caminha). Síntese dos resultados dos trabalhos efectuados em 2007-2009 Mário Varela Gomes

599 Gravuras rupestres de barquiformes no Monte de S. Romão, Guimarães, Noroeste de Portugal Daniela Cardoso

613 Círculos segmentados gravados na Bacia do Rio Lima (Noroeste de Portugal): contributos para o seu estudo Diogo Marinho / Ana M.S. Bettencourt / Hugo Aluai Sampaio

631 Equídeos gravados no curso inferior do Rio Mouro, Monção (NW Portugal). Análise preliminar Coutinho, L.M. / Bettencourt, A.M.S / Sampaio, Hugo A.S

645 Paletas na Arte Rupestre do Noroeste de Portugal. Inventário preliminar Bruna Sousa Afonso / Ana M. S. Bettencourt / Hugo A. Sampaio 


\section{Pré-História}

661 O projeto Miño/Minho: balanço de quatro anos de trabalhos arqueológicos Sérgio Monteiro-Rodrigues / João Pedro Cunha-Ribeiro / Eduardo Méndez-Quintas / Carlos Ferreira / Pedro Xavier / José Meireles / Alberto Gomes / Manuel Santonja / Alfredo Pérez-González

677 A ocupação paleolítica da margem esquerda do Baixo Minho: a indústria lítica do sítio de Pedreiras 2 (Monção, Portugal) e a sua integração no contexto regional Carlos Ferreira / João Pedro Cunha-Ribeiro / Sérgio Monteiro-Rodrigues / Eduardo Méndez-Quintas / Pedro Xavier / José Meireles / Alberto Gomes / Manuel Santonja / Alfredo Pérez-González

693 O sítio acheulense do Plistocénico médio da Gruta da Aroeira Joan Daura / Montserrat Sanz / Filipa Rodrigues / Pedro Souto / João Zilhão

703 As sociedades neandertais no Barlavento algarvio: modelos preditivos com recurso aos SIG

Daniela Maio

715 A utilização de quartzo durante o Paleolítico Superior no território dos vales dos rios Vouga e Côa

Cristina Gameiro / Thierry Aubry / Bárbara Costa / Sérgio Gomes / Luís Luís / Carmen Manzano / André Tomás Santos

733 Uma perspetiva diacrónica da ocupação do concheiro do Cabeço da Amoreira (Muge, Portugal) a partir da tecnologia lítica Joana Belmiro / João Cascalheira / Célia Gonçalves

745 Novos dados sobre a Pré-história Antiga no concelho de Palmela. A intervenção arqueológica no sítio do Poceirão I

Michelle Teixeira Santos

757 Problemas em torno de Datas Absolutas Pré-Históricas no Norte do Alentejo Jorge de Oliveira

771 Povoamento pré-histórico nas áreas montanhosas do NO de Portugal: o Abrigo 1 de Vale de Cerdeira Pedro Xavier / José Meireles / Carlos Alves

783 Apreciação do povoamento do Neolítico Inicial na Baixa Bacia do Douro. A Lavra I (Serra da Aboboreira) como caso de estudo Maria de Jesus Sanches

797 O Processo de Neolitização na Plataforma do Mondego: os dados do Sector C do Outeiro dos Castelos de Beijós (Carregal do Sal)

João Carlos de Senna-Martinez / José Manuel Quintã Ventura / Andreia Carvalho / Cíntia Maurício

823 Novos trabalhos na Lapa da Bugalheira (Almonda, Torres Novas) Filipa Rodrigues / Pedro Souto / Artur Ferreira / Alexandre Varanda / Luís Gomes / Helena Gomes / João Zilhão

837 A pedra polida e afeiçoada do sítio do Neolítico médio da Moita do Ourives (Benavente, Portugal)

César Neves

857 Casal do Outeiro (Encarnação, Mafra): novos contributos para o conhecimento do povoamento do Neolítico final na Península de Lisboa.

Cátia Delicado / Carlos Maneira e Costa / Marta Miranda / Ana Catarina Sousa

873 Stresse infantil, morbilidade e mortalidade no sítio arqueológico do Neolítico Final/ Calcolítico ( $4^{\circ}$ e $3^{\circ}$ milénio a.C.) do Monte do Carrascal 2 (Ferreira do Alentejo, Beja) Liliana Matias de Carvalho / Sofia N. Wasterlain 
885 Come together: O Conjunto Megalítico das Motas (Monção, Viana do Castelo) e as expressões Campaniformes do Alto Minho Ana Catarina Basílio / Rui Ramos

899 Trabalhos arqueológicos no sítio Calcolítico da Pedreira do Poio Carla Magalhães / João Muralha / Mário Reis / António Batarda Fernandes

913 O sítio arqueológico de Castanheiro do Vento. Da arquitectura do sítio à arquitectura de um território João Muralha Cardoso

925 Estudo zooarqueológico das faunas do Calcolítico final de Vila Nova de São Pedro (Azambuja, Portugal): Campanhas de 2017 e 2018 Cleia Detry / Ana Catarina Francisco / Mariana Diniz / Andrea Martins / César Neves / José Morais Arnaud

943 As faunas depositadas no Museu Arqueológico do Carmo provenientes de Vila Nova de São Pedro (Azambuja): as campanhas de 1937 a 1967 Ana Catarina Francisco / Cleia Detry / César Neves / Andrea Martins / Mariana Diniz / José Morais Arnaud

959 Análise funcional de material lítico em sílex do castro de Vila Nova de S. Pedro (Azambuja, Portugal): uma primeira abordagem Rafael Lima

971 O recinto da Folha do Ouro 1 (Serpa) no contexto dos recintos de fossos calcolíticos alentejanos

António Carlos Valera / Tiago do Pereiro / Pedro Valério / António M. Monge Soares

\section{Proto-História}

987 Produção de sal marinho na Idade do Bronze do noroeste Português. Alguns dados para uma reflexão

Ana M. S. Bettencourt / Sara Luz / Nuno Oliveira / Pedro P. Simões / Maria Isabel C. Alves / Emílio Abad-Vidal

1001 A estátua-menir do Pedrão ou de São Bartolomeu do Mar (Esposende, noroeste de Portugal) no contexto arqueológico da fachada costeira de entre os rios Neiva e Cávado Ana M. S. Bettencourt / Manuel Santos-Estévez / Pedro Pimenta Simões / Luís Gonçalves

1015 O Castro do Muro (Vandoma/Baltar, Paredes) - notas para uma biografia de ocupação da Idade do Bronze à Idade Média

Maria Antónia D. Silva / Ana M. S. Bettencourt / António Manuel S. P. Silva / Natália Félix

1031 Do Bronze Final à Idade Média - continuidades e hiatos na ocupação de Povoados em Oliveira de Azeméis João Tiago Tavares / Adriaan de Man

1041 As faunas do final da Idade do Bronze no Sul de Portugal: leituras desde o Outeiro do Circo (Beja)

Nelson J. Almeida / Íris Dias / Cleia Detry / Eduardo Porfírio / Miguel Serra

1055 A Espada do Monte das Oliveiras (Serpa) - uma arma do Bronze Pleno do Sudoeste Rui M. G. Monge Soares / Pedro Valério / Mariana Nabais / António M. Monge Soares

1065 São Julião da Branca (Albergaria-a-Velha) - Investigação e valorização de um povoado do Bronze Final

António Manuel S. P. Silva / Paulo A. P. Lemos / Sara Almeida e Silva / Edite Martins de Sá

1083 Do castro de S. João ao Mosteiro de Santa Clara: notícia de uma intervenção arqueológica, em Vila do Conde Rui Pinheiro 
1095 O castro de Ovil (Espinho), um quarto de século de investigação - resultados e questões em aberto

Jorge Fernando Salvador / António Manuel S. P. Silva

1111 O Castro de Salreu (Estarreja), um povoado proto-histórico no litoral do Entre Douro e Vouga

Sara Almeida e Silva / António Manuel S. P. Silva / Paulo A. P. Lemos / Edite Martins de Sá

1127 Castro de Nossa Senhora das Necessidades (Sernancelhe): uma primeira análise artefactual Telma Susana O. Ribeiro

${ }_{1141}$ A cividade de Bagunte. O estado atual da investigação Pedro Brochado de Almeida

1153 Zoomorfos na cerâmica da Idade do Ferro no NW Peninsular: inventário, cronologias e significado Nuno Oliveira / Cristina Seoane

1163 Vasos gregos em Portugal: diferentes maneiras de contar a história do intercâmbio cultural na Idade do Ferro

Daniela Ferreira

1175 Os exotica da necrópole da Idade do Ferro do Olival do Senhor dos Mártires (Alcácer do Sal) no seu contexto regional

Francisco B. Gomes

\section{Antiguidade Clássica e Tardia}

1191 O uso de madeira como combustível no sítio da Quinta de Crestelos (Baixo Sabor): da Idade do Ferro à Romanização Filipe Vaz / João Tereso / Sérgio Simões Pereira / José Sastre / Javier Larrazabal Galarza / Susana Cosme / José António Pereira / Israel Espi

1207 Cultivos de Época Romana no Baixo Sabor: continuidade em tempos de mudança? João Pedro Tereso / Sérgio Simões Pereira / Filipe Santos / Luís Seabra / Filipe Vaz

1221 A casa romana na Hispânia: aplicação dos modelos itálicos nas províncias ibéricas Fernanda Magalhães / Diego Machado / Manuela Martins

1235 As pinturas murais romanas da Rua General Sousa Machado, n. ${ }^{5}$ 1, Chaves José Carvalho

1243 Trás do Castelo (Vale de Mir, Pegarinhos, Alijó) - Uma exploração agrícola romana do Douro

Tony Silvino / Pedro Pereira

1255 A sequência de ocupação no quadrante sudeste de Bracara Augusta: as transformações de uma unidade doméstica Lara Fernandes / Manuela Martins

1263 Os Mosaicos com decoração geométrica e geométrico-vegetalista dos sítios arqueológicos da área do Conuentus Bracaraugustanus. Novas abordagens quanto à conservação, restauro, decoração e datação Maria de Fátima Abraços / Licínia Wrench

1277 “Casa Romana” do Castro de São Domingos (Cristelos, Lousada): Escavação, Estudo e Musealização Paulo André de P. Lemos

1291 A arqueobotânica no Castro de Guifões (Matosinhos, Noroeste de Portugal): O primeiro estudo carpológico

Luís Seabra / Andreia Arezes / Catarina Magalhães / José Varela / João Pedro Tereso 
1305 Um Horreum Augustano na Foz do Douro (Monte do Castelo de Gaia, Vila Nova de Gaia) Rui Ramos

1311 Ponderais romanos na Lusitânia: padrões, formas, materiais e contextos de utilização Diego Barrios Rodríguez

1323 Um almofariz centro-itálico na foz do Mondego

Marco Penajoia

1335 Estruturas romanas de Carnide - Lisboa Luísa Batalha / Mário Monteiro / Guilherme Cardoso

1347 O contexto funerário do sector da "necrópole NO" da Rua das Portas de S. Antão (Lisboa): o espaço, os artefactos, os indivíduos e a sua interconectividade na interpretação do passado Sílvia Loja, José Carlos Quaresma, Nelson Cabaço, Marina Lourenço, Sílvia Casimiro, Rodrigo Banha da Silva, Francisca Alves-Cardoso

${ }_{1361}$ Povoamento em época Romana na Amadora - resultados de um projeto pluridisciplinar Gisela Encarnação / Vanessa Dias

1371 A Arquitectura Residencial em Mirobriga (Santiago do Cacém): contributo a partir de um estudo de caso Filipe Sousa / Catarina Felício

${ }_{1385}$ O fim do ciclo. Saneamento e gestão de resíduos nos edifícios termais de Mirobriga (Santiago do Cacém)

Catarina Felício / Filipe Sousa

1399 Balsa, Topografia e Urbanismo de uma Cidade Portuária Vítor Silva Dias / João Pedro Bernardes / Celso Candeias / Cristina Tété Garcia

1413 No Largo das Mouras Velhas em Faro (2017): novas evidências da necrópole norte de Ossonoba e da sua ocupação medieval Ricardo Costeira da Silva / Paulo Botelho / Fernando Santos / Liliana Nunes

1429 Instrumentos de pesca recuperados numa fábrica de salga em Ossonoba (Faro) Inês Rasteiro / Ricardo Costeira da Silva / Paulo Botelho

1439 A Necrópole Romana do Eirô, Duas Igrejas (Penafiel): intervenção arqueológica de 2016 Laura Sousa / Teresa Soeiro

1457 Ritual, descarte ou afetividade? A presença de Canis lupus familiaris na Necrópole Noroeste de Olisipo (Lisboa)

Beatriz Calapez Santos / Sofia Simões Pereira / Rodrigo Banha da Silva / Sílvia Casimiro / Cleia Detry / Francisca Alves Cardoso

1467 Dinâmicas económicas em Bracara na Antiguidade Tardia Diego Machado / Manuela Martins / Fernanda Magalhães / Natália Botica

1479 Cerâmicas e Vidros da Antiguidade Tardia do Edifício sob a Igreja do Bom Jesus (Vila Nova de Gaia) Joaquim Filipe Ramos

1493 Novos contributos para a topografia histórica de Mértola no período romano e na Antiguidade Tardia Virgílio Lopes

\section{8. Época Medieval}

1511 Cerâmicas islâmicas no Garb setentrional "português": algumas evidências e incógnitas Constança dos Santos / Helena Catarino / Susana Gómez / Maria José Gonçalves / Isabel Inácio / Gonçalo Lopes / Jacinta Bugalhão / Sandra Cavaco / Jaquelina Covaneiro / Isabel Cristina Fernandes / Ana Sofia Gomes 
1525 Contributo para o conhecimento da cosmética islâmica, em Silves, durante a Idade Média Rosa Varela Gomes

1537 Yábura e o seu território - uma análise histórico-arqueológica de Évora entre os séculos VIII-XII José Rui Santos

1547 A encosta sul do Castelo de Palmela - resultados preliminares da escavação arqueológica Luís Filipe Pereira / Michelle Teixeira Santos

1559 A igreja de São Lourenço (Mouraria, Lisboa): um conjunto de silos e de cerâmica medieval islâmica

Andreia Filipa Moreira Rodrigues

1571 O registo material de movimentações populacionais no Médio Tejo, durante os séculos XII-XIII. Dois casos de "sunken featured buildings", nos concelhos de Cartaxo e Torres Novas Marco Liberato / Helena Santos / Nuno Santos

1585 O nordeste transmontano nos alvores da Idade média. Notas para reflexão Ana Maria da Costa Oliveira

1601 Sepulturas escavadas na rocha do Norte de Portugal e do Vale do Douro: primeiros resultados do Projecto SER-NPVD

Mário Jorge Barroca / César Guedes / Andreia Arezes / Ana Maria Oliveira

1619 "Portucalem Castrum Novum" entre o Mediterrâneo e o Atlântico: o estudo dos materiais cerâmicos alto-medievais do arqueossítio da rua de D. Hugo, nํ. 5 (Porto) João Luís Veloso

1627 A Alta Idade Média na fronteira de Lafões: notas preliminares sobre a Arqueologia no Concelho de Vouzela

Manuel Luís Real / Catarina Tente

1641 Um conjunto cerâmico medieval fora de portas: um breve testemunho aveirense Susana Temudo

${ }_{1651}$ Os Lóios do Porto: uma perspetiva integrada no panorama funerário da Baixa Idade Média à Época Moderna em meios urbanos em Portugal

Ana Lema Seabra

1659 O Caminho Português Interior de Santiago como eixo viário na Idade Média Pedro Azevedo

1665 Morfologia Urbana: Um exercício em torno do Castelo de Ourém André Donas-Botto / Jaqueline Pereira

1677 Intervenção arqueológica na Rua Marquês de Pombal/Largo do Espírito Santo (Bucelas, Loures)

Florbela Estêvão / Nathalie Antunes-Ferreira / Dário Ramos Neves / Inês Lisboa

1691 O Cemitério Medieval do Poço do Borratém e a espacialidade funerária na cidade de Lisboa Inês Belém / Vanessa Filipe / Vasco Noronha Vieira / Sónia Ferro / Rodrigo Banha da Silva

1705 Um Espaço Funerário Conventual do séc. XV em Lisboa: o caso do Convento de São Domingos da Cidade Sérgio Pedroso / Sílvia Casimiro / Rodrigo Banha da Silva / Francisca Alves Cardoso

\section{9. Época Moderna e Contemporânea}

1721 Arqueologia Moderna em Portugal: algumas reflexões críticas em torno da quantificação de conjuntos cerâmicos e suas inferências históricas e antropológicas Rodrigo Banha da Silva / André Bargão / Sara da Cruz Ferreira

1733 Faianças de dois contextos entre os finais do século XVI e XVIII do Palácio dos Condes de Penafiel, Lisboa

Martim Lopes / Tomás Mesquita 
1747 Um perfil de consumo do século XVIII na foz do Tejo: O caso do Mercado da Ribeira, Lisboa Sara da Cruz Ferreira / Rodrigo Banha da Silva / André Bargão

1761 Os Cachimbos dos Séculos XVII e XVIII do Palácio Mesquitela e Convento dos Inglesinhos (Lisboa)

Inês Simão / Marina Pinto / João Pimenta / Sara da Cruz Ferreira / André Bargão / Rodrigo Banha da Silva

1775 "Tomar os fumos da erua que chamão em Portugal erua sancta». Estudo de Cachimbos provenientes da Rua do Terreiro do Trigo, Lisboa

Miguel Martins de Sousa / José Pedro Henriques / Vanessa Galiza Filipe

1787 Cachimbos de Barro Caulínitico da Sé da Cidade Velha (República de Cabo Verde)

Rodrigo Banha da Silva / João Pimenta / Clementino Amaro

1801 Algumas considerações sobre espólio não cerâmico recuperado no Largo de Jesus (Lisboa) Carlos Boavida

1815 Adereços de vidro, dos séculos XVI-XVIII, procedentes do antigo Convento de Santana de Lisboa (anéis, braceletes e contas)

Joana Gonçalves / Rosa Varela Gomes / Mário Varela Gomes

1837 Da ostentação, luxo e poder à simplicidade do uso quotidiano: arqueologia e simbologia de joias e adornos da Idade Moderna Portuguesa Jéssica Iglésias

1849 Os amuletos em Portugal - dos objetos às superstições: o coral vermelho Alexandra Vieira

1865 Cerâmicas de Vila Franca de Xira nos séculos XV e XVI Eva Pires

1879 «Não passa por teu o que me pertence». Marcas de individualização associadas a faianças do Convento de Nossa Senhora de Aracoeli, Alcácer do Sal Catarina Parreira / Íris Fragoso / Miguel Martins de Sousa

1891 Cerâmica de Leiria: alguns focos de produção

Jaqueline Pereira / André Donas-Botto

1901 Os Fornos na Rua da Biquinha, em Óbidos Hugo Silva / Filipe Oliveira

1909 A casa de Pêro Fernandes, contador dos contos de D. Manuel I: o sítio arqueológico da Silha do Alferes, Seixal (século XVI) Mariana Nunes Ferreira

1921 O Alto da Vigia (Sintra) e a vigilância e defesa da costa Alexandre Gonçalves / Sandra Santos

1937 O contexto da torre sineira da Igreja de Santa Maria de Loures Paulo Calaveira / Martim Lopes

1949 A Necrópole do Hospital Militar do Castelo de São Jorge e as práticas funerárias na Lisboa de Época Moderna Susana Henriques / Liliana Matias de Carvalho / Ana Amarante / Sofia N. Wasterlain

1963 SAND - Sarilhos Grandes Entre dois Mundos: o adro da Igreja e a Paleobiologia dos ossos humanos recuperados

Paula Alves Pereira / Roger Lee Jesus / Bruno M. Magalhães

1975 Expansão urbana da vila de Cascais no século XVII e XVIII: a intervenção arqueológica na Rua da Vitória no 15 a 17

Tiago Pereira / Vanessa Filipe

1987 Novos dados para o conhecimento do Urbanismo de Faro em época Moderna Ana Rosa 
1995 Um exemplo de Arqueologia Urbana em Alcoutim: o Antigo Edifício dos CTT Marco Fernandes / Marta Dias / Alexandra Gradim / Virgílio Lopes / Susana Gómez Martínez

2007 Palácio dos Ferrazes (Rua das Flores/Rua da Vitória, Porto): a cocheira de Domingos Oliveira Maia

Francisco Raimundo

2021 As muitas vidas de um edifício urbano: História, Arqueologia e Antropologia no antigo Recreatório Paroquial de Penafiel Helena Bernardo / Jorge Sampaio / Marta Borges

2035 O convento de Nossa Senhora da Esperança de Ponta Delgada: o contributo da arqueologia para o conhecimento de um monumento identitário João Gonçalves Araújo / N’Zinga Oliveira

2047 Arqueologia na ilha do Corvo... em busca da capela de Nossa Senhora do Rosário Tânia Manuel Casimiro / José Luís Neto / Luís Borges / Pedro Parreira

2059 Perdidos à vista da Costa. Trabalhos arqueológicos subaquáticos na Barra do Tejo Jorge Freire / José Bettencourt / Augusto Salgado

2071 Arqueologia marítima em Cabo Verde: enquadramento e primeiros resultados do projecto CONCHA

José Bettencourt / Adilson Dias / Carlos Lima / Christelle Chouzenoux / Cristóvão Fonseca / Dúnia Pereira / Gonçalo Lopes / Inês Coelho / Jaylson Monteiro / José Lima / Maria Eugénia Alves / Patrícia Carvalho / Tiago Silva

2085 Trabalhos arqueológicos na Cidade Velha (Ribeira Grande de Santiago, Cabo Verde): reflexões sobre um projecto de investigação e divulgação patrimonial André Teixeira / Jaylson Monteiro / Mariana Mateus / Nireide Tavares / Cristovão Fonseca / Gonçalo C. Lopes / Joana Bento Torres / Dúnia Pereira / André Bargão / Aurélie Mayer / Bruno Zélie / Carlos Lima / Christelle Chouzenoux / Inês Henriques / Inês Pinto Coelho / José Lima / Patrícia Carvalho / Tiago Silva

2103 A antiga fortificação de Quelba / Khor Kalba (E.A.U.). Resultados de quatro campanhas de escavações, problemáticas e perspectivas futuras Rui Carita / Rosa Varela Gomes / Mário Varela Gomes / Kamyar Kamyad

2123 Colónias para homens novos: arqueologia da colonização agrária fascista no noroeste ibérico Xurxo Ayán Vila / José Mạ . Señorán Martín 


\title{
"CASA ROMANA" DO CASTRO DE SÃO DOMINGOS (CRISTELOS, LOUSADA): ESCAVAÇÃO, ESTUDO E MUSEALIZAÇÃO
}

Paulo André de P. Lemos ${ }^{1}$

\begin{abstract}
RESUMO
No presente artigo dão-se a conhecer os resultados dos trabalhos arqueológicos efetuados no assentamento romano na meia encosta do monte de São Domingos, no âmbito do projeto de investigação "Escavação, estudo e musealização da "Casa Romana" do Castro de São Domingos”. Este projeto, que surgiu da vontade expressa da autarquia de Lousada em levar a cabo um estudo clarificador e de valorização do espaço arqueológico, sob a coordenação científica do signatário, ainda que aberto à participação de outros colaboradores/investigadores. Palavras-chave: Época Romana, Idade do Ferro, Fossas, Sepulturas.
\end{abstract}

\begin{abstract}
In this article we present the results of archaeological work carried out in the Roman settlement on the halfslope of the hill of São Domingos, included in the research project "Excavation, study and musealization of the "Casa Romana" (Roman House) of the Hillfort of São Domingos". This project arises from the expressed intention of the local authority of Lousada to carry out a clarifying and valorization study of the mentioned archaeological place, under the scientific coordination of the signatory, although opened to the participation of other collaborators/investigators.
\end{abstract}

Keywords: Roman period, Iron Age, Dug pits, Graves.

\section{RESUMO DO PROJETO}

O desenvolvimento dos trabalhos arqueológicos (concretamente as intervenções levadas a cabo por José Marcelo Sanches Mendes-Pinto) e a progressiva revelação da importância científica e patrimonial do Castro de São Domingos (o povoado fortificado encontra-se em vias de classificação) levaram a autarquia de Lousada a desenvolver, entre 2009-2011, o projeto de investigação “A 'Casa Romana' do Castro de São Domingos: intervenção arqueológica e valorização patrimonial”, que tinha como premissa a conservação e salvaguarda de toda a informação correlacionada com o assentamento romano na meia encosta do monte de São Domingos. O mencionado projeto foi estruturado em quatro fases: 1) ações de escavação arqueológica; 2) realização de estudos sedimentológicos, arqueométricos, antracológicos, geológicos, palinológicos e datações por radiocarbono; 3) ações de estudo e tratamento de materiais provenientes das anteriores intervenções realizadas no Castro de São Domingos, na década de 1990;4) ações de conservação, restauro e valorização.

A primeira etapa foi efetuada numa superfície superior a $500 \mathrm{~m}^{2}$, numa tentativa de definição do potencial arqueológico do espaço, esclarecendo a situação do assentamento romano na meia encosta do monte de São Domingos, apurando o seu estado de conservação e caracterizando novos elementos arqueológicos. No que concerne à segunda fase, graças a um protocolo com o Laboratório do Porto da Direção-Geral de Energia e Geologia, foi realizado um conjunto de estudos de cariz geológico, com vista à clarificação das hipóteses aventadas para uma das funcionalidades das fossas identificadas no povoado, nomeadamente a sua utilização na atividade

1. Arqueólogo coordenador do Projeto de Investigação Escavação, Estudo e Musealização da "Casa Romana” do Castro de São Domingos; paplemos@gmail.com 
extrativa de material argiloso para utilização nas estruturas murais das diversas construções da designada "Casa Romana" (Nunes et al., 2011, pp. 72-82; Novais et al., 2014, pp. 213-215).

Contudo, refira-se que o supramencionado projeto de investigação não foi, por imperativos financeiros, concluído. Com o intuito de terminar a intervenção arqueológica e a respetiva valorização patrimonial do sítio, o atual projeto de investigação, denominado de "Escavação, estudo e musealização da 'Casa Romana' do Castro de São Domingos”, foi delineado para os anos de 2017 a 2020, sob a coordenação científica do signatário, contando com a colaboração de António Manuel dos Santos Pinto da Silva, como consultor científico. Deste modo, e com o desígnio de alcançar os resultados propostos, foram delineados vários objetivos, necessariamente apoiados em metodologias adequadas e condições de financiamento estáveis, asseguradas pela autarquia de Lousada, estruturadas em três fases: a) escavação arqueológica (numa superfície de $1500 \mathrm{~m}^{2}$ ); b) estudos sedimentológicos, arqueométricos, antracológicos, geológicos, palinológicos e datações por radiocarbono; e, finalmente, c) conservação, restauro e valorização do sítio. Mediante os resultados previstos dos trabalhos planeados, pretende-se, na conclusão do projeto, uma clarificação e valorização do espaço arqueológico do assentamento romano na meia encosta do monte de São Domingos.

\section{CASTRO DE SÃO DOMINGOS}

2.1. Antecedentes. Descoberta do sítio arqueológico e trabalhos realizados

A primeira referência documental ao Castro de São Domingos regista-se nas Inquirições de D. Afonso II de 1258 (Academia das Ciências de Lisboa, 18881897, fl. 547), onde se refere que "Item quod habetur ibi unum castrum et fuit populatum: et dixit quod omnes qui morantur in ipsa villa partierunt illud se et laborant illud".

Mais tarde, nos primórdios do século XVIII, o padre Carvalho da Costa, refere-se ao povoado nos seguintes termos: "Aqui está o Monte de Crasto de S. Domingos, que tomou este nome de huma Capella que teve deste Santo: tem sinais de fortificação, que pelo nome suppomos ser dos Romanos" (Costa, 1706, p. 400). Em 188o Francisco Martins Sarmento, “em visita ao local tece as primeiras considerações científicas sobre o povoado. Nessa visita [...] descreve-o como tendo sido um povoado fortificado onde ainda eram visíveis várias linhas de muralha. Refere ainda o achado de diversos fragmentos cerâmicos que considerou de cronologia romana" (Nunes, Sousa e Gonçalves, 2008, p. 106).

Já no século XX (1957), D. Domingos de Pinho Brandão foi o primeiro autor a divulgar e a recolher materiais de superfície do castro (Mendes-Pinto, 2008, p. 51). Ao longo do século XX, outros autores se debruçaram sobre este povoado e/ou o espólio dele proveniente, designadamente: Vieira (1887, p. 355), Alarcão (1958, pp. 249-315), Lanhas (1971, pp.574575), Silva (1986), Dias (1997) (Nunes, et al. 2008, p 106) e, finalmente, Mendes-Pinto (Nunes, Sousa e Gonçalves, 2007, pp. 1-4, 2008, p. 106; Mendes-Pinto, 2008, pp. 51-52) tendo aqui realizado campanhas arqueológicas na década de 1990.

\subsection{Descrição do sítio arqueológico}

$\mathrm{O}$ castro de São Domingos $\left(41^{\circ} 16^{\prime} 31.50^{\prime \prime} \mathrm{N}\right.$; $08^{\circ} 17^{\prime} 45.96^{\prime \prime}$ ), localizado na União de freguesias de Cristelos, Boim e Ordem, concelho de Lousada e distrito do Porto, retira o nome de uma antiga capela que terá existido no topo do monte, dedicada a São Domingos, e que, à semelhança de muitos outros locais, tinha como finalidade a cristianização do sítio (Sarmento, 188o apud Guimarães, 1989, pp. 26-27; Mendes-Pinto, 2008, p. 51). (Figura 1)

Constituindo o maior e mais bem preservado povoado proto-histórico identificado ao longo da bacia do Mezio, território que atualmente se insere, na sua quase totalidade, no concelho de Lousada, o povoado, apesar de uma intensa humanização da paisagem envolvente (florestação, rede viária e construção civil), conserva importantes vestígios associados ao povoamento da Idade do Ferro, correspondentes às denominadas Fase IIA e IIB (século VI a.C. à segunda metade do século III a.C.) e Fase IIIA e IIIB (século II a.C. à segunda metade do século I a.C.) da "cultura dos castros" (Nunes, et. al., 2007, p. 1). Atingiu, segundo Martins (1990, p. 206), por volta do século II a.C. e sensivelmente até à segunda metade do século I, portanto já no quadro da romanização, o seu período optimum (Nunes, et. al., 2007, p. 1).

O Castro de São Domingos apresenta-se como "um povoado fortificado de médias dimensões, implantado num outeiro cónico isolado que domina visualmente todo o vale do rio Mezio e apresenta ótimas condições naturais de defesa" (Mendes-Pinto 
1995, p. 273), claramente percetível na paisagem e em notória dominância e centralidade relativamente aos demais povoados implantados na bordadura montanhosa que ladeia o vale do Mezio (Nunes, et al., 2007, p. 2), onde, e de acordo com a tese defendida por Ferreira da Silva (1980, p. 88), a distribuição destes povoados, longe de ser anárquica, poderia obedecer a uma certa hierarquização, cabendo, com alguma certeza, ao povoado de São Domingos um certo grau de preponderância, que, no entanto, ainda não nos é inteiramente percetível (Nunes, et al., 2007, p. 2) (Figura 2).

O povoado de São Domingos, "possui três linhas de muralhas, correspondentes a cada uma das três grandes plataformas aí visíveis, separadas por fortes declives, onde se terão inscrito preferentemente as estruturas habitacionais" (Mendes-Pinto 1995, p. 273). As escavações aqui realizadas permitiram constatar duas realidades distintas: uma primeira, nas cotas acima dos $300 \mathrm{~m}$, onde persiste uma área onde os vestígios se encontram relativamente bem preservados, e uma segunda, situada abaixo da cota dos $300 \mathrm{~m}$, onde a realidade arqueológica foi sendo alvo de perturbações, mais ou menos evidentes.

A conquista, e consequente destruição do povoado, provavelmente no decurso das Guerras Cantábricas (26-19 a.C.), é apontada por Mendes-Pinto como ponto de partida para uma "reorganização espacial do povoado, com o reordenamento interno dos núcleos familiares, que passam a ser compostos por unidades circulares e unidades sub-retangulares ou quadrangulares cercadas por um muro e dando para um grande pátio lajeado, onde se processavam algumas das principais atividades domésticas, notando-se desde logo a adaptação à cultura romana e a influência mediterrânica da casa-pátio. [...] Talvez pelos finais da primeira metade do século I, ou inícios da sua segunda metade, vemos a coroa do monte ser paulatinamente abandonada em favor das plataformas da meia-encosta, quando se começam a construir casas já tipicamente romanas" (Mendes-Pinto, 2008, p. 6o). “[É] no decurso deste processo de reordenamento defendido por [Mendes-Pinto] que se verificou a construção de um pólo habitacional romano (século I a $\mathrm{V}$ d.C.), implantado na encosta virada a Sudeste" (Nunes, et al., 2008, p. 107). Do espólio proveniente do monte de São Domingos "destaca-se a presença de cerâmica de importação, nomeadamente ânforas vinárias Alterne 70 e Dressel 20 (século I-II d.C.), e ainda várias sigillatas, entre as quais um fragmento de fundo de sigillata hispânica, possível forma Drag.27, com marca de oleiro, de ângulos curvos onde se pode ler OFVAPA, isto é, proveniente da oficina do oleiro Valerius Paternus, de Tritium Magallum (atual Tricio, Espanha)" (Nunes, et. al., 2007, p. 4). A ocupação do monte de São Domingos "perdurará pelo menos até aos inícios do século $\mathrm{V}$, época da chegada dos bárbaros, quando terá sido destruída a habitação [romana a meia-encosta] por meio de novo incêndio" (Mendes-Pinto, 2008, p. 6o).

\subsection{Descrição do assentamento romano na meia encosta do monte de São Domingos}

$\mathrm{O}$ assentamento romano na meia encosta do monte de São Domingos corresponde a uma área implantada na sua vertente sudeste e na qual se insere a faixa de terreno intervencionada em 1996 pelo arqueólogo Mendes-Pinto, designada de "Casa Romana".

$\mathrm{Na}$ mencionada vertente foram detetados "restos de muros e abundantes fragmentos de tegula e cerâmica comum romana a indiciarem a presença de importantes vestígios arqueológicos" (Mendes-Pinto, 2008, p. 55). De acordo com o mencionado autor (2008, p. 55), estes indícios de ocupação romana do espaço foram percetíveis graças aos trabalhos das máquinas de um empreiteiro que realizou trabalhos de terraplenagem, com o objetivo de proceder à construção de um prédio habitacional. As escavações levadas a cabo por Mendes-Pinto (2008, pp. 55-56) revelaram os restos de uma casa romana, que apropriou um pátio lajeado e uma antiga habitação circular. Foram escavados dois compartimentos: o primeiro, no extremo nordeste, de planta quadrangular, com cerca de $4,5 \mathrm{~m}$ de lado, possui porta virada a sudeste, pela qual comunicava com uma sala (da qual apenas subsiste $\mathrm{o}$ arranque de uma das paredes e vestígios de um piso em terra batida); o segundo compartimento encontra-se incompleto, mas apresentaria planta retangular, com largura mínima de $4 \times 6 \mathrm{~m}$, ao qual Mendes-Pinto atribui uma cronologia provável do século I. No exterior da casa, no seu lado sudoeste, encontrou-se um lajeado de um pátio pertencente a uma habitação de planta circular. A casa romana sofreu um incêndio, sendo, posteriormente, alvo de uma remodelação, que lhe reduziu o espaço anexo (provavelmente na segunda metade do século III). O nível de circulação foi alteado em cerca de $0,80 \mathrm{~m}$, reaproveitando-se para esse fim parte dos derrubes da anterior construção. Des- 
sa edificação mais antiga apenas chegaram até nós os vestígios inferiores dos seus muros e dos seus pisos em terra batida e compactada. Sobre estes, um derrube de tegulae e imbrex comprova o desmoronamento do telhado, originado, uma vez mais, por um incêndio, presumivelmente em meados do século $\mathrm{V}$, aquando da invasão Visigoda (Mendes-Pinto, 2008, p. 56).

\section{RESULTADOS PRELIMINARES DA INTERVENÇÃO}

As ações desenvolvidas no âmbito do atual projeto de investigação na vertente SE do castro, numa superfície de $988 \mathrm{~m}^{2}$, possibilitaram a perceção da dinâmica ocupacional do espaço, revelando uma considerável potência e complexidade estratigráfica, tendo sido identificadas uma multiplicidade de níveis ocupacionais de diferentes cronologias.

$\mathrm{Na}$ parte central da área intervencionada foi, primeiramente, identificado o muro [388], de Época Contemporânea/Moderna, composto por pedras de corneana, com ocasionais de granito, de médias a grandes dimensões, equivalendo a reaproveitamentos de anteriores estruturas, sendo percetíveis, por exemplo, fragmentos de mós de vaivém. Ostenta apenas uma face, com os interstícios preenchidos por pedras de pequenas dimensões e terra pouco compacta. Este muro, conjuntamente com os muros [389] e [409] da Idade do Ferro, delimita o espaço concernente a um antigo caminho que serpenteia o terreno no sentido SO.-NE., com largura média de 1,10 m, sendo percetível numa extensão de $13 \mathrm{~m}$, associado a um nível de circulação, que fazia a ligação entre a zona do vale do rio Mezio e o topo do monte de São Domingos, de acesso a uma antiga capela que terá existido no topo do monte, dedicada a São Domingos (Figura 3 ).

No limite SO. da área escavada foi identificada uma estrutura de delimitação do espaço, de Época Medieval, percetível numa extensão superior a $12 \mathrm{~m}$, com 1,70 $\mathrm{m}$ de largura média e uma altura máxima de $0,50 \mathrm{~m}$. Equivale a um amontoado de pedras estruturadas, mas não argamassadas, com ocasionais fragmentos de tegulae, envoltas por terras, originando uma espécie de "muralha" edificada no sentido N.-S (Figura 4 e 5).

Em direta associação a esta estrutura foram identificadas seis sepulturas que atestam a utilização cemiterial do espaço. A totalidade dos sepulcros apresen- tam orientação SO-NE., de forma semiretangulares, encontrando-se abertos no geológico natural. A té ao momento foram escavados três sepulcros (Sepulturas 1, 2 e 3) uma vez que as restantes não foram, ainda, delimitadas na sua totalidade. De entre as sepulturas identificadas a Sepultura 2 revelou ser a mais recente sendo as restantes, aparentemente, coevas, achando-se compostas por pedras de corneana e granito de médias dimensões. A Sepultura 1, composta por pedras de corneana e granito de médias dimensões, apresenta 1,70 $\mathrm{m}$ de comprimento, 0,40 $\mathrm{m}$ de largura na cabeceira e $0,30 \mathrm{~m}$ de largura nos pés (dimensões internas). Não revelou quaisquer vestígios de inumação, apresentando somente uma unidade deposicional formada por terras homogéneas, soltas, de cor castanho-escura, de grão médio a fino, com escasso espólio cerâmico repartido entre cerâmica de uso doméstico da Idade do Ferro (n=10) e de pequenos fragmentos de tegula $(n=3)$, além de um fragmento de escória metálica.

A Sepultura 2, formada por pedras de corneana e granito de médias dimensões, ostenta $1,74 \mathrm{~m}$ de comprimento, o, $42 \mathrm{~m}$ de largura na cabeceira e o,20 $\mathrm{m}$ de largura nos pés (dimensões internas). Não revelou vestígios de inumação, apresentando parte das lajes da tampa de cobertura. Revelou estar preenchida por dois depósitos. O primeiro formado por terras homogéneas, soltas, de cor castanho-escura e de grão médio a fino, patenteando apenas 2 diminutos fragmentos de tegula. A unidade subsequente revelou possança inferior a $5 \mathrm{~cm}$, sendo composta por terras heterogéneas, desagregadas, argilosas de grão fino, cor castanho-escura, com frequentes bolsas saibrentas de cor bege/laranja (Figura 6).

A Sepultura 3, constituída por pedras de corneana e granito de médias dimensões, revelou 1,74 $\mathrm{m}$ de comprimento, $0,40 \mathrm{~m}$ de largura na cabeceira e 0,32 $\mathrm{m}$ de largura nos pés (dimensões internas). Não revelou vestígios de inumação, apresentando somente dois depósitos. O primeiro correspondia a um nível de terras homogéneas, medianamente compactas, cor castanho claro, grão fino a médio, com frequente espólio cerâmico repartido por fragmentos cerâmicos da Idade do Ferro ( $\mathrm{n}=31)$ e fragmentos de Época Romana (tegula) $(\mathrm{n}=5)$. A última unidade identificada equivalia a um depósito de terras homogéneas, soltas, de cor castanho-escuro e grão médio a fino, com ocasionais fragmentos cerâmicos $(n=19)$ da Idade do Ferro.

A Sepultura 4 foi percetível em cerca de metade, 
prolongando-se para a área não intervencionada. Constituída por pedras de corneana de médias a pequenas dimensões, com o,7o $\mathrm{m}$ de comprimento (não totalmente delimitada) por o,42 $\mathrm{m}$ de largura (dimensões internas), não ostentando lajes da tampa de cobertura, o que indicia que a mesma tenha sido aberta e violada em altura indeterminada.

A Sepultura 5 foi parcialmente delimitada, uma vez que a mesma se prolonga para além da área intervencionada, sendo apenas visível duas pedras de granito de grandes dimensões e uma de corneana de pequenas dimensões. Está em mau estado de conservação tendo sido truncada aquando dos trabalhos abertura da Travessa Nossa Senhora Conceição.

Finalmente, a Sepultura 6 é constituída por pedras de corneana e granito de médias dimensões, não estando totalmente delimitada, apresentando $1,80 \mathrm{~m}$ de comprimento por $0,38 \mathrm{~m}$ de largura (dimensões internas).

As ações desenvolvidas revelaram igualmente a presença de níveis ocupacionais correlacionados com a ocupação de Época Romana, ainda que em mau estado de conservação. Desta cronologia foram identificadas duas estruturas habitacionais.

A primeira [187], localizada nos quadrados H/I18-19, apresenta 5,70 m (SO.-NE.) x 1.80 m (NO.-SE.), perfazendo um espaço interno mínimo de $10 \mathrm{~m}^{2} \mathrm{com}-$ posto por pedras de granito e ocasionais de corneana. A segunda estrutura [399]/[505]/[550]/[566], ostenta forma quadrangular $(4,80 \times 4,80 \mathrm{~m}) \mathrm{com}$ uma área interna de $23 \mathrm{~m}^{2}$, porta voltada a SO., com 1,10 m de largura, e paredes constituídas, essencialmente, por pedras de granito de médias dimensões, com interstícios preenchidos por pedras de granito de pequenas dimensões, fragmentos de tegula e terras argilosas. As paredes [399] e [566] apresentam-se em toda a sua extensão, ainda que esta última esteja ligeiramente danificada na sua parte interna. As paredes [505] e [550] estão destruídas nos seus limites, concretamente no lado sul da habitação. Destas edificações apenas chegaram até nós os vestígios inferiores dos seus muros não tendo sido identificados os seus pisos. A correlação destas duas estruturas, aparentemente coevas, com a designada "Casa Romana" identificada e intervencionada por Mendes-Pinto (ver ponto 2.3.) é de difícil análise, sendo, contudo, de admitir a possibilidade de fazerem parte de uma mesma orgânica habitacional, cujos limites/ funções se nos afiguram de difícil perceção.

Relacionada com a ocupação da Idade do Ferro fo- ram identificadas mais de uma dezena de estruturas habitacionais, de três fases ocupacionais distintas. Estas revelaram, na sua generalidade, por contraponto com as estruturas habitacionais de Época Romana, serem compostas por pedras de corneana de pequeno a médio porte, com interstícios preenchidos por terras saibrentas compactas. Associadas a estas estruturas foram identificados pisos de circulação compostos por saibro compacto, ou por terras barrentas, argilosas de tonalidade laranja, cozidas in situ, com indícios de combustão. Ainda em associação a esta realidade foram identificados, em quatro situações, a remanescência de pátios abertos e lajeados, circunscritos por muros.

A ocupação corelacionada com a Idade do Ferro baliza-se entre o século IV a I a.C. encontra-se separada dos níveis de Época Romana por uma sequência de depósitos com inclusão de material cerâmico de produção local e cerâmica importada. Estas unidades comprovam uma dinâmica ocupacional muito intensa, com uma sobreposição de espaços habitacionais e áreas funcionais, cuja sincronia se afigura, por vezes, de difícil perceção (Figura 7).

De entre as estruturas conotadas com esta época temos a evidenciar, dada a sua particularidade, a presença da estrutura habitacional [672] (Quadrados $\mathrm{L} / \mathrm{M} / \mathrm{N}$ io a 12) em que o uso de argila foi primordial na sua edificação, sendo contemporânea de edifícios em alvenaria de pedra mais tradicionais dentro do que se conhece da arquitetura deste período no território em que o povoado se localiza. Corresponde a uma casa de planta circular com 4,80 m de diâmetro que seria constituída por uma parede composta por terras saibrentas-argilosas de grão fino a médio, cor laranja, com inclusão de pedras de corneana de pequenas dimensões, com o,50 m de largura, circunscrevendo uma área interna com 3,90 m de diâmetro, perfazendo uma área útil de $12,25 \mathrm{~m}^{2}$. A entrada, com 1,55 m de largura estava orientada a este. $O$ seu piso de circulação [67o] está nivelado, sendo composto por saibro muito compacto, de grão médio a grosso, de cor bege/amarelo com zonas de tonalidade laranja. Na parte central desta estrutura habitacional foi identificado um bloco de corneana de forma trapezoidal, com o topo plano, relacionado com o apoio do respetivo teto, não tendo, contudo, sido identificadas estruturas de combustão. $\mathrm{Na}$ área exterior, na envolvente à casa, foi colocado um lajeado composto por pedras de corneana e ocasionais de granito, de médias a grandes dimensões, de entre as 
quais se destacam a incorporação de fragmentos de mós de vaivém e de moinhos manuais rotativos. As lajes apresentam indícios de desgaste e correspondem a um nível de circulação relacionado com a utilização da casa e com o espaço envolvente (Figura 8). Anterior a toda esta realidade foram identificadas 63 fossas escavadas no geológico natural, ocupando o espaço de forma aparentemente aleatória. De morfologia variável apresentam perfil, ora arredondado, ora ovalado ou mesmo irregular, ainda que os seus contornos não sejam, na sua maioria, completamente regularizados. A diversidade de formas e dimensões poderá relacionar-se, entre outros fatores, com questões de funcionalidade, com características específicas dos produtos a armazenar, ou acesso aos mesmos. Assim, sendo provável, ou pelo menos admissível, a utilização dos materiais inertes retirados das fossas para a obtenção de argamassas, não resulta claro se esta extração se realizou per si nem, tampouco, as razões que levaram a uma extração "cuidada", atribuindo às fossas formas arredondadas, mais próprias de silos que de "barreiros" ou "saibreiras" onde a extração segue filões de matéria-prima sem preocupações arquitetónicas (Figura 9). Por outro lado, a avaliar pelos indícios detetados na Fossa 19, nitidamente isolada com argamassa de saibro na zona de contacto com a Fossa 18, é aceitável a hipótese de estarmos, pelo menos em algumas das fossas, perante uma situação de dupla funcionalidade. Isto é, a abertura de estruturas tipo silo, no geológico seria feita provavelmente com o intuito de armazenagem de alimentos, e num momento subsequente, far-se-ia o aproveitamento dos materiais argilosos disponibilizados durante o processo de escavação. Sendo de presumir que a ordem dos eventos seja esta, não é de descartar uma relação causal distinta. Com efeito, a situação inversa - a abertura de cavidades para a extração de materiais argilosos e o seu posterior afeiçoamento para servir como estrutura de armazenamento - não tendo suporte arqueológico evidente, possui suporte geológico, já que os materiais extraídos foram utilizados na produção de argamassas para as estruturas habitacionais da Idade do Ferro (Nunes, et. al., 2018, pp.426-227) (Figura 10).

A nível temporal e cronológico, foi possível definir distintos momentos que presidiram à abertura das fossas, dado que se entrecruzam com alguma frequência, ainda que muito provavelmente essas fases construtivas se efetivem num tempo muito próximo entre si. Em termos latos, esse momento construtivo cristaliza-se numa fase anterior às estruturas habitacionais presentes na designada "Casa Romana". Embora seja crível que a época construtiva das fossas possa recuar aos primórdios da ocupação do povoado, não podemos ignorar que a abertura de fossas é uma constante entre as comunidades da Idade do Bronze, pelo que a pervivência destas estruturas na Idade do Ferro reforça a ideia de uma certa continuidade entre o Bronze Final e a Idade do Ferro.

\section{CONCLUSÕES}

As ações desenvolvidas no âmbito do atual projeto de investigação, entre os anos de 2017 e 2019, na vertente SE. do Castro de São Domingos, numa superfície de $988 \mathrm{~m}^{2}$, permitiram a perceção da dinâmica ocupacional do espaço, revelando uma considerável potência e complexidade estratigráfica, ainda que o terreno tenha sido afetado pelos trabalhos de terraplenagem efetuados na década de 1990, aquando da preparação do terreno para a edificação das residências familiares.

No que concerne às três sepulturas intervencionadas as mesmas foram, infelizmente, abertas e violadas em altura indeterminada e o conteúdo que outrora poderão ter encerrado foi perdido, tendo sido apenas recuperado escasso espólio da Idade do Ferro e de época Romana. No verão de 2020 a área de escavação será alargada às sepulturas 4, 5 e 6 e focar-se-á na procura do templo religioso a que a necrópole deverá ter estado associada, assim como no melhor enquadramento da sua cronologia que, por comparação com os poucos contextos ibéricos idênticos, não poderá, para já, ser mais específica dentro da Época Medieval. Apesar do contexto do sítio parecer indicar que assumiu importância na região, apenas se suspeita que na zona mais elevada do povoado terá, em tempos, existido uma ermida evocativa do santo que deu nome ao monte.

As rochas das estruturas associadas ao assentamento romano na meia encosta do monte de São Domingos podem ser agrupadas em dois conjuntos distintos, relacionáveis com a idade dos vestígios em estudo. As estruturas da Idade do Ferro apresentam quase exclusivamente corneanas, que se encontram em afloramento na envolvente ao local do edificado. As estruturas de época romana, contêm corneanas e granito de Lousada. Os locais que constituem fonte provável das rochas são o Monte de São Domingos 
para as corneanas e um contato com o granito de Lousada nas imediações do mesmo topónimo. Consequentemente, a evolução de uma cultura da Idade do Ferro para uma de influência romana é acompanhada de uma descida na altitude da extração da rocha, bem como numa movimentação do processo extrativo em direção a este, possivelmente a partir do século I d.C.

As fossas são as estruturas mais numerosas desta estação arqueológica, contudo, são aquelas que postam mais problemas do ponto de vista interpretativo. Tendo em conta a sua morfologia diversa, a sua estrutura geológica, o seu contexto arqueológico e, ainda, alguns paralelos regionais, como o povoado fortificado do Lago (Amares) ou do povoado do Crastoeiro (Mondim de Basto), foram aventadas diversas interpretações relativas à(s) sua(s) funcionalidade(s). Parcas na informação, facultando apenas um vislumbre da sua arquitetura ou, as mais das vezes, o momento da sua inutilização enquanto estruturas, a maioria das fossas desempenhou, pelo menos na fase final da sua vida útil, uma função detrítica, tendo sido intencionalmente entulhadas, indicando, assim, um terminus ante quem para as estruturas que se lhe sobrepõem. Conquanto a função detrítica prevaleça sobre as demais no registo arqueológico, é de crer que a função primordial fosse outra. Os paralelos com outras fossas detetadas em habitats da Idade do Bronze Final, no contexto regional, são evidentes, e permitem considerar a hipótese de algumas destas estruturas terem sido utilizadas como fossas de aprovisionamento, vulgarmente denominados "silos", destinadas à armazenagem de bens alimentares.

\section{BIBLIOGRAFIA}

ALARCÃO, A. M. (1958) - Sigillata hispânica em museus do Norte de Portugal. In Revista Guimarães: 68 (3-4), pp. 249-315.

LANHAS, F. (1971) - Lousada: Arqueologia. Enciclopédia Luso-Brasileira da Cultura, Volume 12. Lisboa: Editorial Verbo, pp.574-575.

MARTINS, M. (1990) - O Povoamento Proto-histórico e a Romanização da bacia do Curso Médio do Cavado. In Cadernos de Arqueologia. Monografias. Braga.

MENDES-PINTO, J.M.S. (1995) - O Povoamento da bacia superior do Rio Sousa: da Proto-História à Romanização. Trabalhos de Antropologia e Etnologia. In Atas do $1^{\circ}$ Congresso de Arqueologia Peninsular. Vol. V. Porto: Sociedade Portuguesa de Antropologia e Etnologia, pp. 265-283.
MENDES-PINTO,J.M.S.(2008)-Do castro deS.Domingos a Meinedo: Proto-história e Romanização na bacia superior do rio Sousa. In Oppidum - Revista de Arqueologia, História e Património, número especial, Câmara Municipal de Lousada, pp. 45-63.

NOVAIS, H., LEMOS, P., LEITE, J., NUNES, M. (2014) - As rochas do edificado da "Casa Romana" (Cristelos - Lousada). Variação cronológica da sua tipologia e origem. In $O p$ pidum. N.ำ 7 . Lousada: CML, pp. 211-216.

NUNES, M.; SOUSA, L. e GONÇALVES, C. (2007) - O Castro de S. Domingos (Cristelos - Lousada): algumas notas sobre a sua ocupação durante a Idade do Ferro e Época Romana. In Revista Municipal, ano 8, 3. ․ㅗ' Série, n. ${ }^{4}$ 45, setembro, Suplemento de Arqueologia, Município de Lousada, pp. 1-4.

NUNES, M., SOUSA, L. e GONÇALVES, C. (2008) - Carta Arqueológica do concelho de Lousada, Gabinete de Arqueologia, Câmara Municipal de Lousada, pp. 41-46/106-107.

NUNES, M.; LEMOS, P.; LEITE, J.; NOVAIS, H.; OLIVEIRA, A. (2011) - Estruturas negativas da "Casa Romana" do Castro de São Domingos (Lousada): as fossas escavadas no saibro. In Oppidum - Revista de Arqueologia, História e Património, N.ำ 5 , Câmara Municipal de Lousada, pp. 61-84.

NUNES, M.; LEMOS, P.; LEITE, J.; NOVAIS, H. (2018) - Estruturas negativas no sítio arqueológico da "Casa Romana" do Castro de São Domingos (Lousada): as fossas escavadas no saibro. In GUTIÉRREZ, Noelia H.; GALARZA, Javier L.; HERNÁNDEZ, Rodrigo P (coord.) Investigaciones arqueológicas en el valle del Duero: del Paleolítico a la Edad Media 6 - Actas de las VI Jornadas de Arqueología del valle del Duero (Oporto, 2016). Espanha: Zamoraprotohistorica, pp. 419-427.

SARMENTO, F. M. (1880) - Antiqua. Manuscritos inéditos de Francisco Martins Sarmento (Informes, reconhecimentos e prospeções). Guimarães: Sociedade Martins Sarmento, [Anotados por F.J. Salgado Guimarães], pp. 26-27.

SILVA, Armando Coelho Ferreira da (1980) - Organizações Gentilícias entre Leça e Ave. Portugália. Nova Série, vol. I. Porto, pp. 79-9o.

SILVA, Armando Coelho Ferreira da (1986) - A Cultura Castreja no Noroeste de Portugal, Dissertação de Doutoramento em Pré-História e Arqueologia, Apresentada à Faculdade de Letras da Universidade do Porto, Câmara Municipal de Paços de Ferreira, Museu Arqueológico da Citânia de Sanfins. 


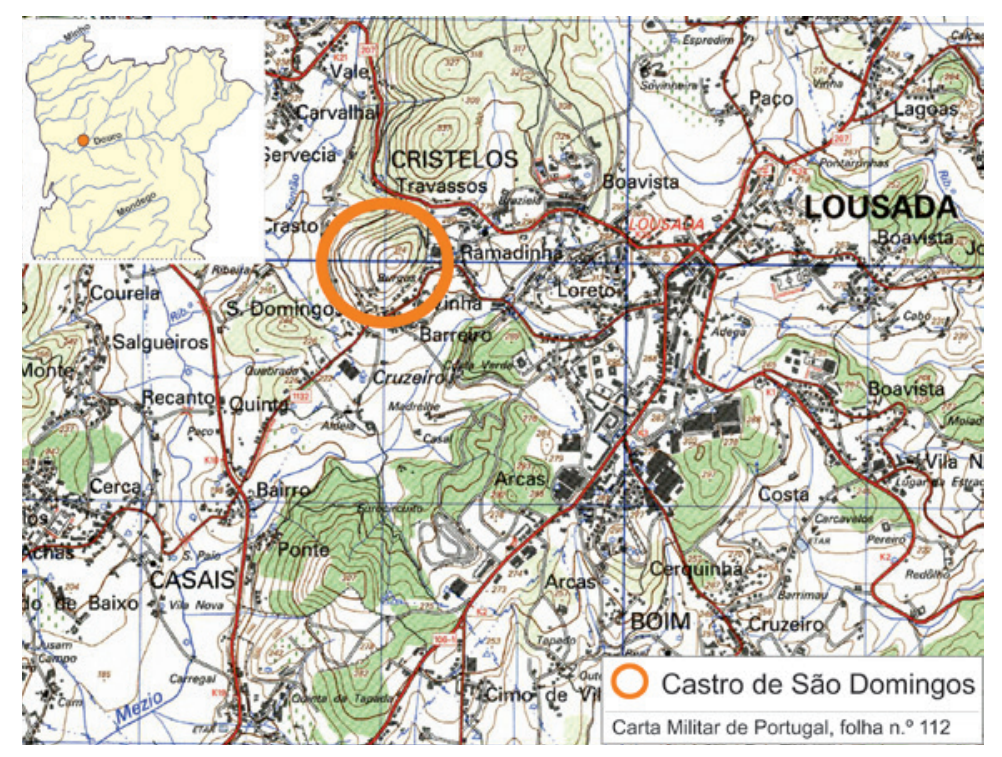

Figura 1 - Localização do Castro de São Domingos (Cristelos, Lousada) (IGeoE, 1998).

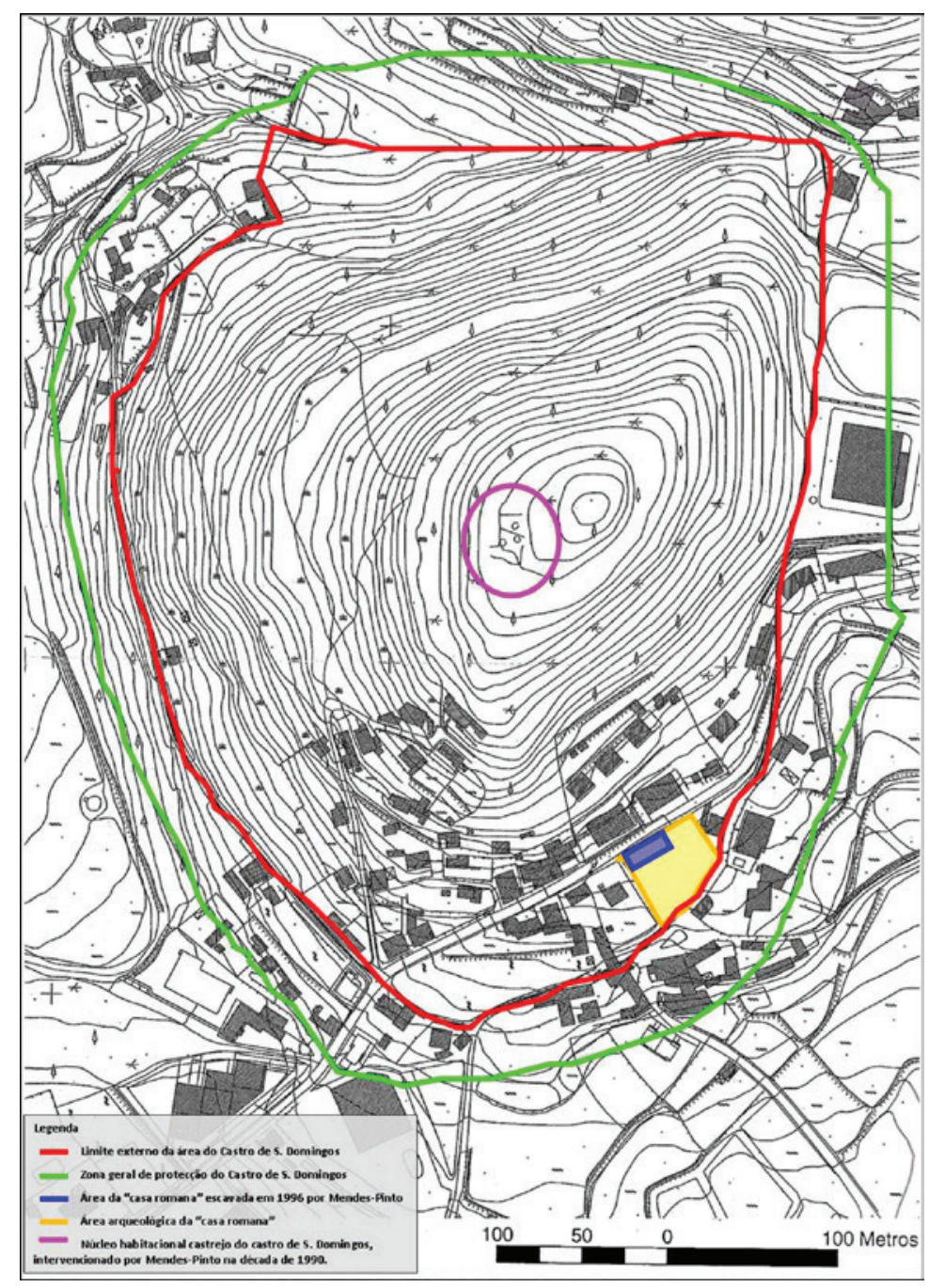

Figura 2 - Planta topográfica do Castro de São Domingos. (Fonte: Câmara Municipal Lousada). 


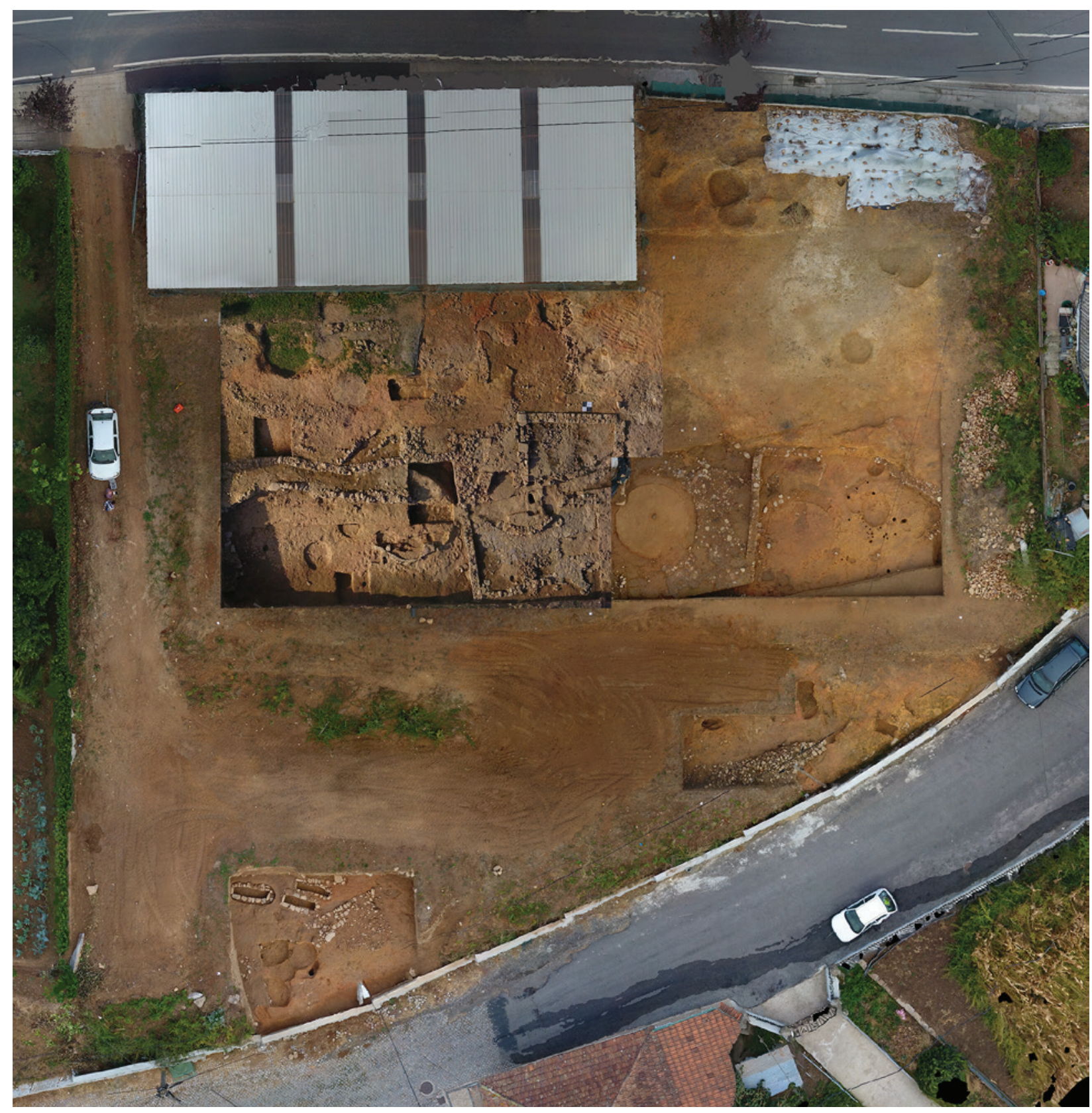

Figura 3 - Fotografia aérea da designada “Casa Romana” do Castro de São Domingos (António Alfredo da Silva da Mota Leitão). 


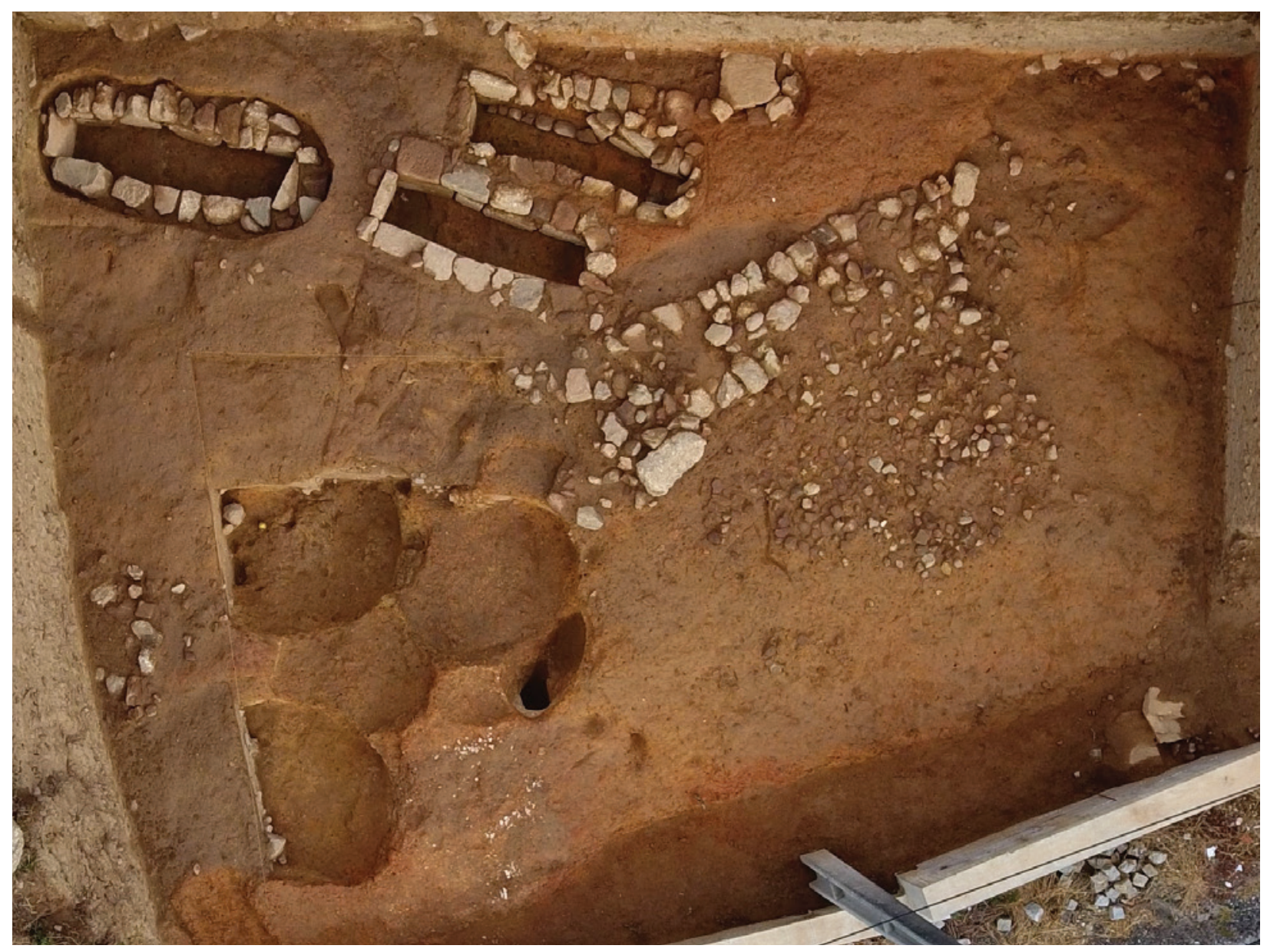

Figura 4 - Fotografia aérea da estrutura de delimitação e das sepulturas (António Alfredo da Silva da Mota Leitão). 


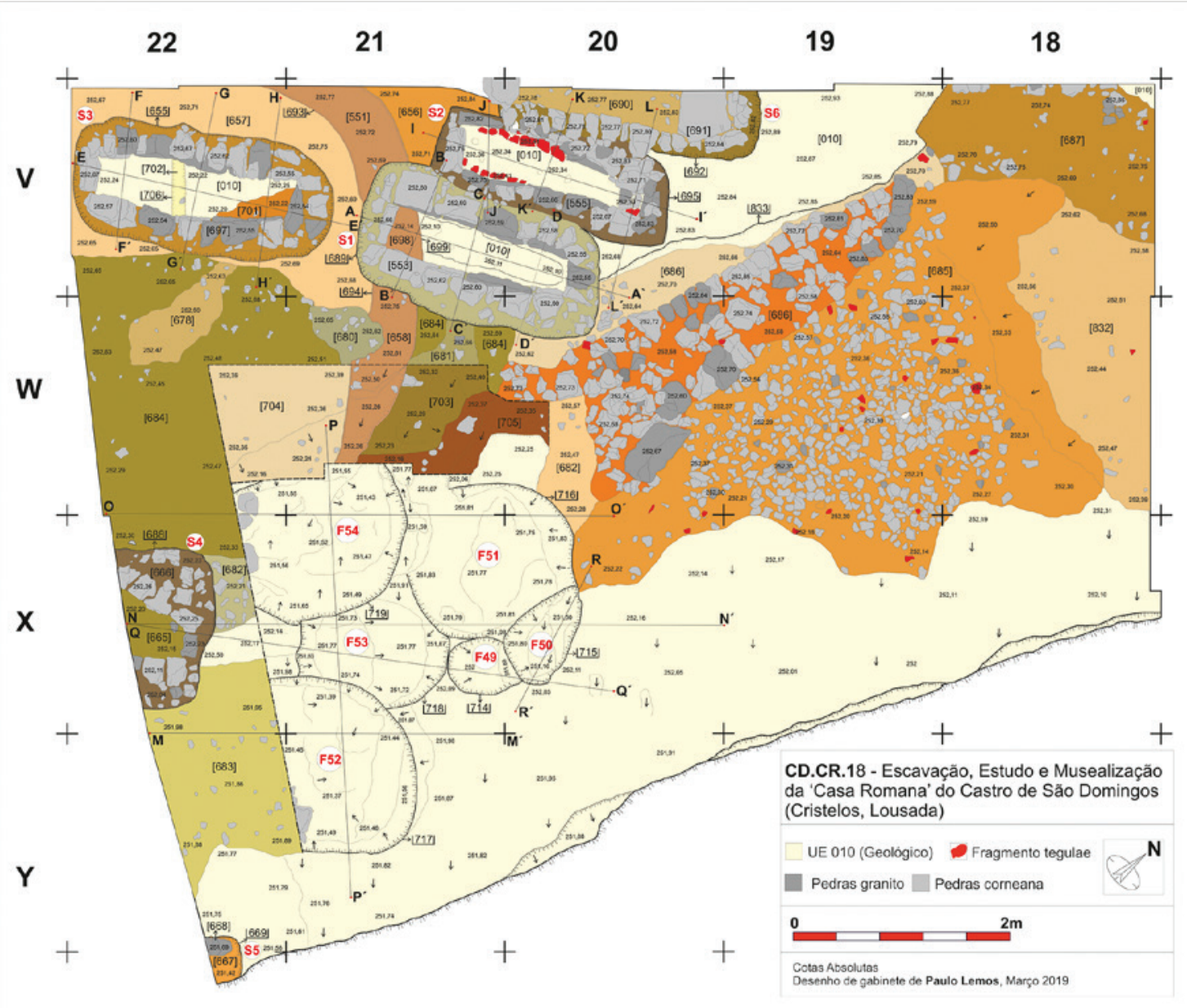

Figura 5 - Pormenor da estrutura de delimitação e das sepulturas.

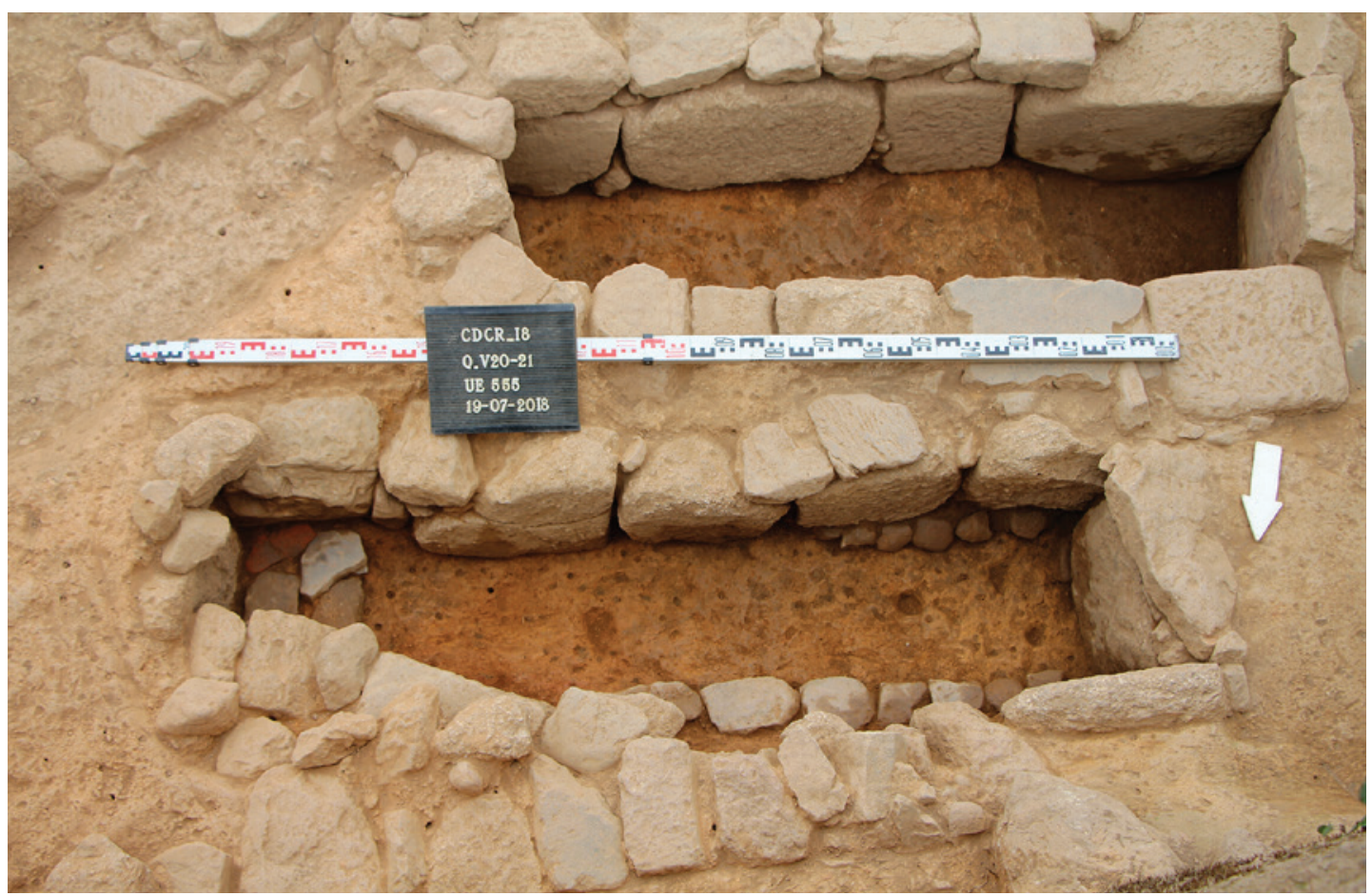

Figura 6 - Pormenor das sepulturas 1 e 2. 


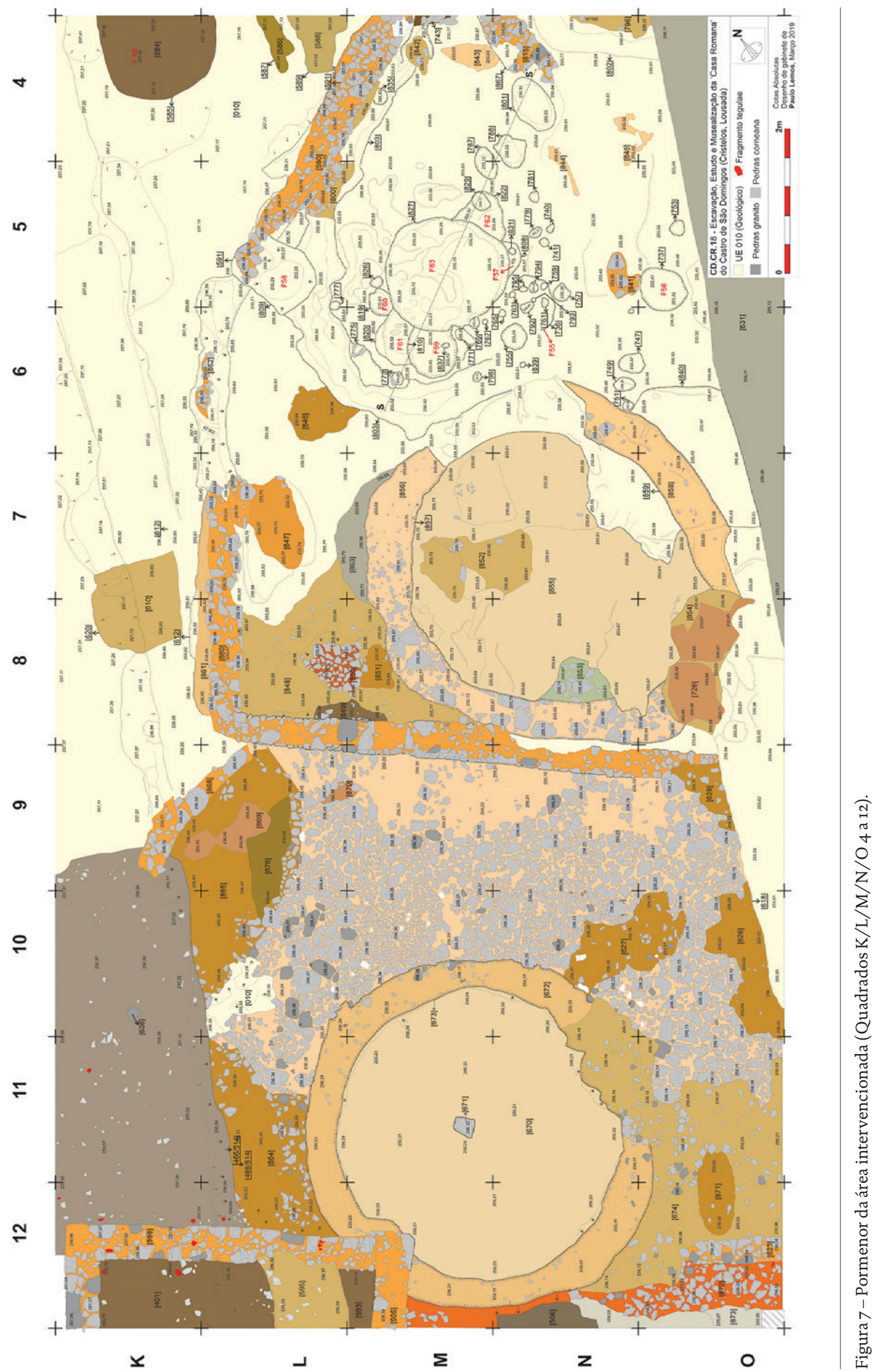




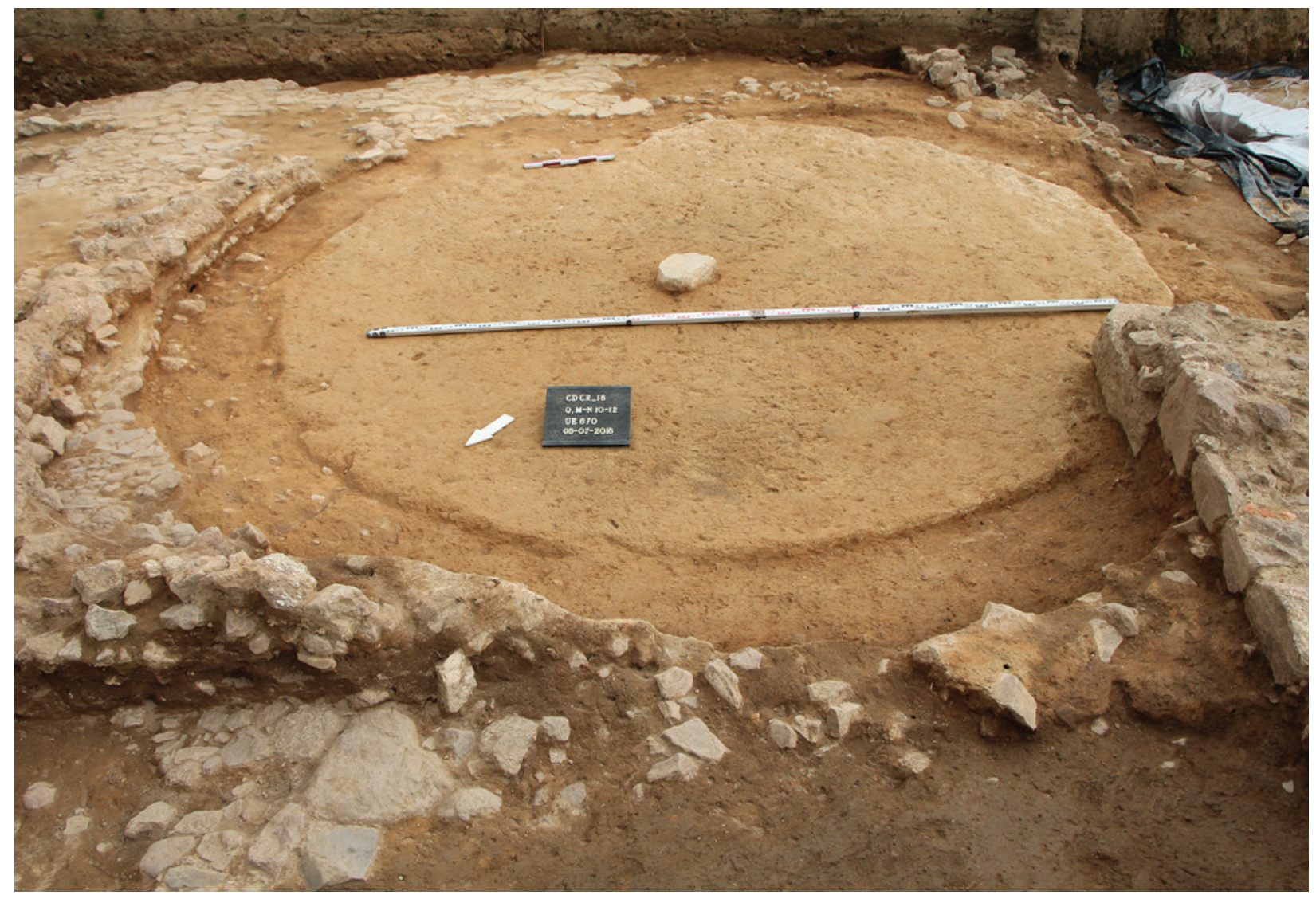

Figura 8 - Pormenor da estrutura habitacional [672].

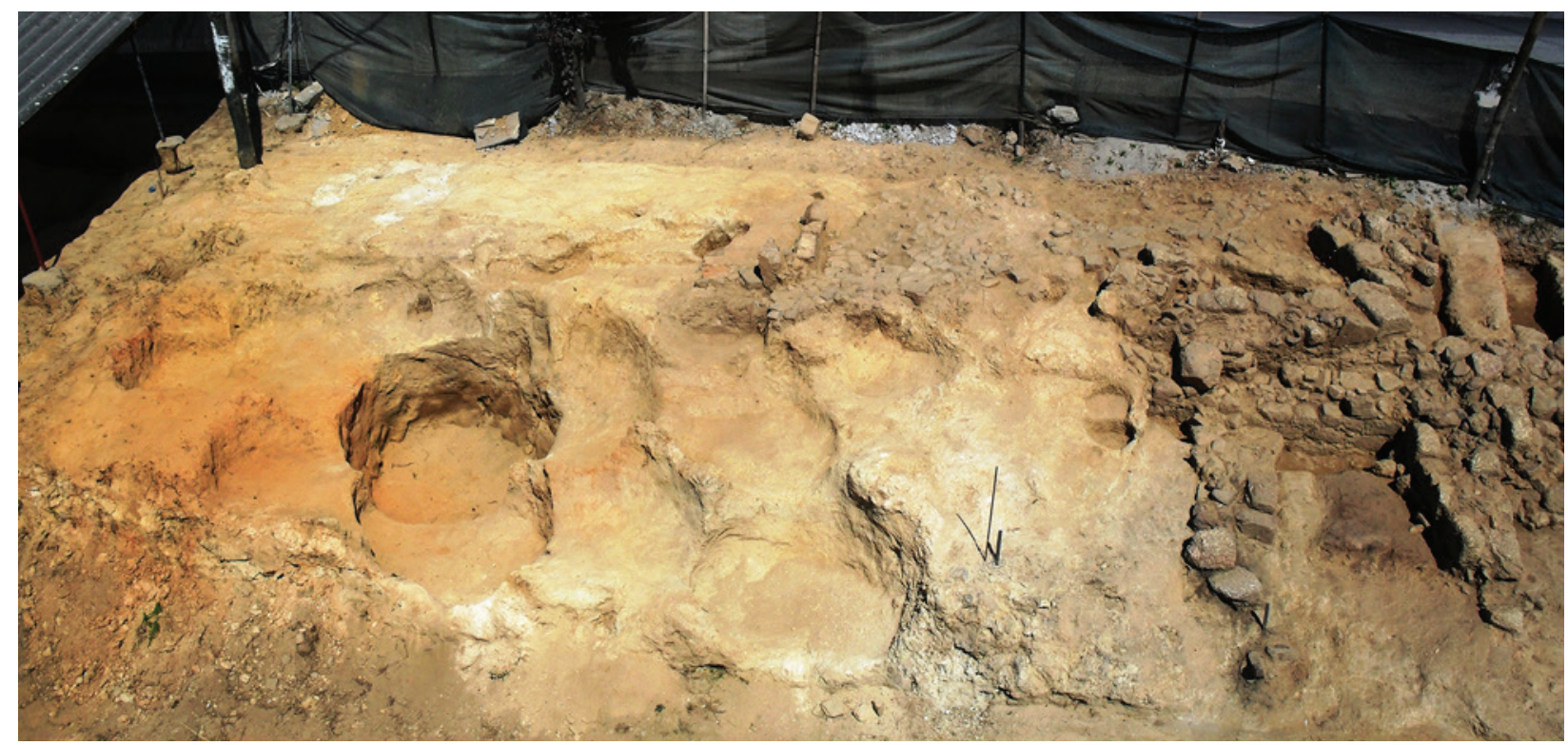

Figura 9 - Fotografia aérea do limite NO da designada “Casa Romana” do Castro de São Domingos (Manuel da Mota Nunes). 


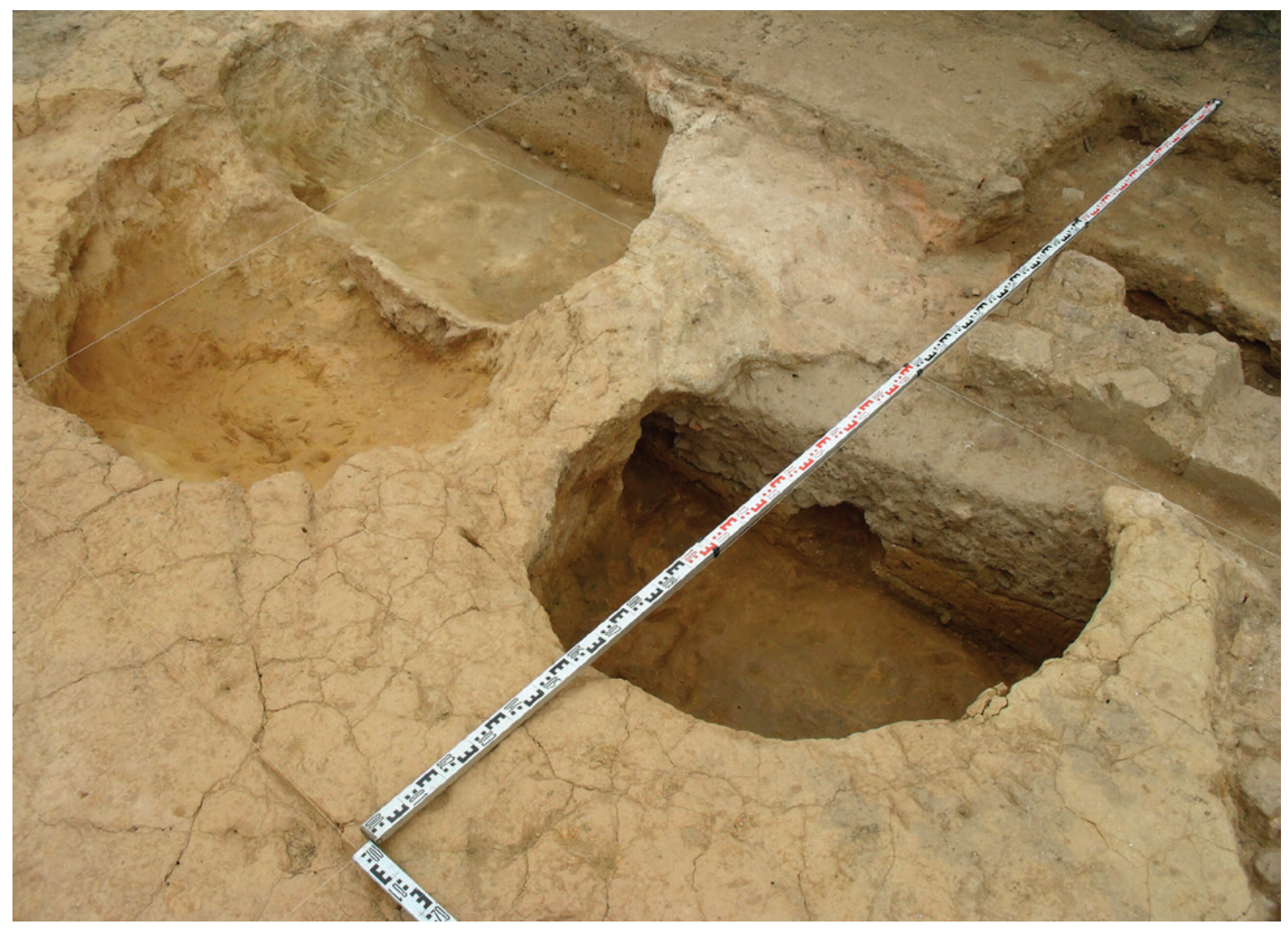

Figura 10 - Aspeto final dos trabalhos realizados nas Fossas 17 a 20. 



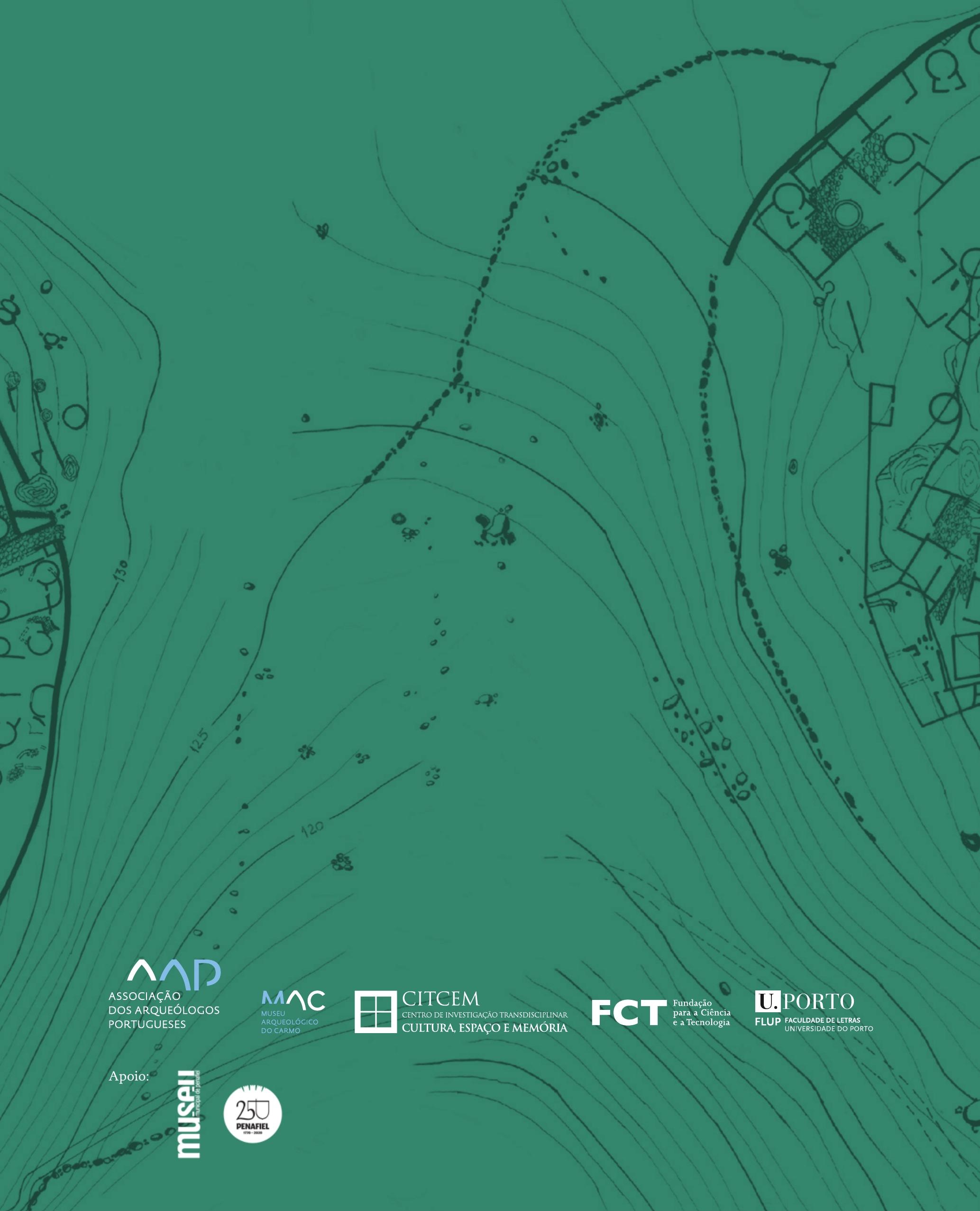

